Portland State University

PDXScholar

Fall 1-7-2020

\title{
Competing Narratives: the Struggle for the Soul of Egypt
}

Ahmed El Mansouri

Portland State University

Follow this and additional works at: https://pdxscholar.library.pdx.edu/open_access_etds

Part of the Near and Middle Eastern Studies Commons, Peace and Conflict Studies Commons, and the Political Science Commons

Let us know how access to this document benefits you.

\section{Recommended Citation}

El Mansouri, Ahmed, "Competing Narratives: the Struggle for the Soul of Egypt" (2020). Dissertations and Theses. Paper 5363.

https://doi.org/10.15760/etd.7236

This Thesis is brought to you for free and open access. It has been accepted for inclusion in Dissertations and Theses by an authorized administrator of PDXScholar. Please contact us if we can make this document more accessible: pdxscholar@pdx.edu. 
Competing Narratives: The Struggle for the Soul of Egypt

by

Ahmed El Mansouri

A thesis submitted in partial fulfillment of the requirements for the degree of

Master of Science

in

Conflict Resolution

Thesis Committee:

Harry Anastasiou, Chair

Rachel Cunliffe

Robert Gould

Portland State University

2019 
(C) 2019 Ahmed El Mansouri 
Abstract

In January 2011, Egypt witnessed an uprising against ex-military president Hosni Mubarak, which resulted in his removal after ruling Egypt for thirty years. Yet, while the revolution targeted Mubarak, it also targeted to end the era of military rule, which started in 1952 with President Gamal Abdel Nasser, then was passed down to Anwar Sadat in 1970 and later to Hosni Mubarak in 1981. Thereafter, dissatisfied with existing national policies, political leaders and revolutionaries battled to redefine Egyptian national identity by contesting the writing of a new Egyptian constitution. The debates over the constitution exhibited an ample of destructive communication patterns that triggered my research question and hypotheses. In this thesis, I pose the question as to how a critical analysis of the communication patterns of the conflict actors involved elucidates Egypt's current state of affairs. The outcomes showed that the calm after an approved constitution in January 2014, and the return of the military to power in June 2014, maybe the silence before another revolutionary storm, because many underlining issues remain unresolved. In this thesis, I argue that the equivocal nature of Egyptian national identity and the exclusivist nature of the nationalistic approaches utilized to determine it were core elements that added to the conflict's lengthiness and exacerbation. Moreover, I show that the lack of understanding of these aggravating elements among the parties involved is due to the absence of positive dialogue that may aid in their deconstruction. To conclude, I explain through Egypt's bygone narrative how psychological layers, that begin with postcolonial-trauma and end with sheer distrust, are what hinder positive dialogical approaches amid the parties concerned. 


\section{Dedication}

To my parents, for their unconditional embracement through all of my accomplishments 
I would like to acknowledge the following individuals for their contributions, their enthusiasm, and their cooperation in supporting this thesis: Harry Anastasiou, chair of this thesis and director of the Conflict Resolution Program at Portland State University, for his in-depth support with the overarching vision and the theoretical, analytical, and recommendation sections in this thesis; Rachel Cunliffe, a committee member for this thesis and faculty member at Portland State University, for her remarkable assistance with the methodology section in this thesis; and Robert Gould, a committee member for this thesis and faculty member at Portland State University, for allowing me to explore the philosophical and psychological aspects presented in this thesis. In addition, I would like to acknowledge Professor Amanda Byron for further help with the methodology section, Arabic professor Lina Gomaa for help with the Arabic-English translations needed for this thesis, and editor Jennifer Zaczek for copyediting this thesis.

Finally, I am genuinely grateful to both of my boys, Yusuf and Noah, for their young hearted inspiration of innocence and peace, and to my mentors and colleagues, particularly Carol Gabrielli, who have graciously offered time to inquire and reflect on the initial proposal for this thesis; their contributions were a major component in my ability to produce a comprehensive analysis. 


\section{Table of Contents}

Abstract

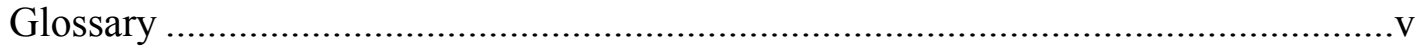

Chapter 1

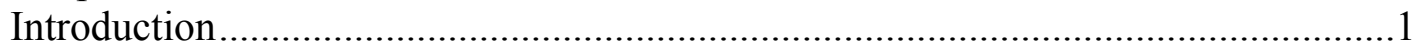

Chapter 2

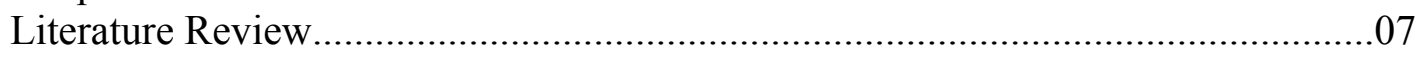

Chapter 3

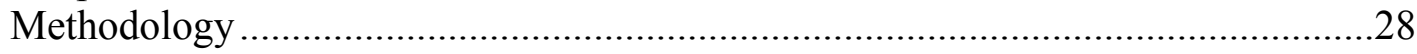

Chapter 4

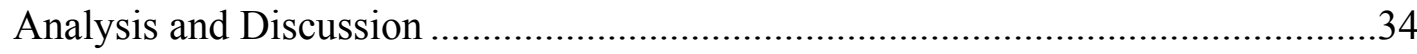

Chapter 5

Conclusions and Recommendations ...................................................... 90

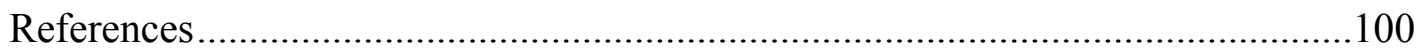




\begin{abstract}
Alashwaeyat: Buildings built by the members of Egypt's poorest communities without any engineering or architectural guidance, thus they face overcrowding and other social and public health issues due to their poor engineering structures.
\end{abstract}

Article II of the Egyptian constitution (1971-2013): States that Islam is the religion of the State and Arabic is its official language. The principles of Islamic Sharia are the main source of legislation.

Caliphate: A state under the leadership of an Islamic steward known as the caliph, a person considered a religious successor of the Islamic prophet Muhammad and a leader of the entire Muslim community. Historically, the caliphates were polities based in Islam, which developed into multiethnic transnational empires. During the medieval period, three major caliphates existed: the Rashidun Caliphate (632-661), the Umayyad Caliphate (661-750), and the Abbasid Caliphate (750-1258). The fourth major caliphate, the Ottoman Caliphate, was a manifestation whereby the Ottoman rulers claimed caliphal authority.

Cornish: A platform or boardwalk along a river (Nile) or seashore (Alexandria coast).

Fatwa: In the Islamic faith, a nonbinding but authoritative legal opinion or learned interpretation that a qualified jurist or mufti can give on issues pertaining to Islamic law.

Fava beans or ful medames: A dish of cooked fava beans served with vegetable oil, cumin, and optionally with chopped parsley, garlic, onion, lemon juice, chili pepper, and other vegetables, herbs, and spices; notably a food staple in Egypt.

Flare point: A term used to describe certain communicational exchanges that were heated and intense in nature and may or may not have led to violence.

House of Representatives: The lower house of the Egyptian parliament; the unicameral parliament of Egypt.

Imam: An Islamic leadership position most commonly used as the title of a worship leader of a mosque and Muslim community among Sunni Muslims. In this context, imams may lead Islamic worship services, serve as community leaders, and provide religious guidance.

Master-narrative: A narrative that combines two or more sub-narratives with similar or varying national ideologies but agree on the conflict topic (The constitution).

Mufti: The person who issues a fatwa. In Egypt, the word is mostly used to refer to the Grand Imam of Al-Azhar Mosque, as he is the main figure in issuing the final fatwa on 
controversial religious matters. This is not necessarily a formal position, since most Muslims argue that anyone trained in Islamic law may give an opinion on its teachings.

Narrative: The story told by individuals through certain metaphors, symbols, etc. embodying certain ideologies to normalize their perception of the soul of Egypt.

Normalization: The discursive process by which conflict actors present their identity narrative, which aims to portray that the majority is aware and agrees with the presented information.

Salaf: Relating to the first three generations of Muslims (i.e., the generations of the Islamic prophet Muhammad and his companions, their successors, and the successors of those successors).

Shura Council: The upper house of the formerly bicameral parliament of Egypt.

Sharia, Sharia law, or Islamic law: The religious law derived from the religious precepts of Islam, the holy book (the Qur'an) and the narrations of the prophet Muhammad, the Hadith. Sharia refers to God's immutable divine law and is contrasted with fiqh, which is its human scholarly interpretations. The manner of its application in modern times has been a subject of dispute between Muslim traditionalists and reformists.

Soul of Egypt: A term used in this thesis to reference the national identity of Egypt because it denotes that national identity is a given - an "ordained" identity by God, history, or common sense.

Sub-narrative: A narrative that describes individuals promoting a similar national ideology.

Tarboosh: A short, cylindrical, peakless headdress or hat made of kilim fabric, usually red, and sometimes with a tassel attached to the top. The tarboosh owes much of its development and popularity to the Ottoman era, and is worn especially by Muslim men throughout the Eastern Mediterranean region. 
Chapter 1

Introduction

This thesis is an investigation of the events unfolding in Egypt between 2011 and 2014. These events commence with a people driven revolt against ex-military president Hosni Mubarak in particular, and against military rule in general. My interest in writing a thesis about this Egyptian revolution arose when I learned that in June of 2014 the military had returned to the ruling chair under the leadership of another military general, General Abdel-Fatah Al-Sisi. I instigated my research by reviewing accounts of the events between 2011 and 2014 and instantly noted that a center stage point of contention was the conflicting views on the definition of Egyptian national identity. Yet, what deepened my interest in the study were the destructive communicative patterns utilized by the participants, which often transformed dialogue into debates and debates into violent conflicts. This particular observation triggered me to pose the following research question: How does communication between the narratives shaping the events unfolding in Egypt since the 2011 revolution elucidate the current state of affairs?

In this thesis, I argue that the equivocal nature of Egyptian national identity and the exclusivist nature of the nationalistic approaches as communicative means are major components in making the conflict a continuous struggle. Moreover, I reveal that the lack of understanding for these aggravating elements among the parties involved is due to the absence of positive dialogue that may aid in their deconstruction. Furthermore, I explain how psychological layers that begin with postcolonial-trauma and end with sheer distrust are what hinder positive dialogical ventures. I provide a perspective that competes against the local and international community's concerns with Egypt's future by providing an 
account of the bygone history that has led to Egypt's current national identity predicament.

Thus, before delving into the details of the analysis and the arguments I will put forth, certain elements of Egyptian history are essential to underscore. Egyptian history is notably recorded with the Pharaonic period, were dynasties of the pharaohs (A civilization hypothesized by modern mainstream Egyptians as the origin of Egyptian identity) ruled for almost 3000 years until the Achaemenid Persians conquered Egypt and claimed the title of Pharaoh. When Alexander the Great toppled the Persians, Egypt became the center of a Greek culture that tried to gain the respect of its natives by claiming to be heirs to the Pharaohs. Though Greeks took on Pharaonic traditions and portrayed themselves on public tombstones, they faced revolts from the natives that weakened their position, and ultimately caused them to surrender Egypt to Rome (Hoffman, 1979; Midant-Reynes, 2000; Rawlinson \& Komroff, 1928; Bowman, 1989). Rome presented Egypt with Christianity, an Egyptian translation of the New Testament, and the establishment of the Egyptian Coptic Church of Alexandria. With the Church recognized as second in honor to the Church of Rome, Christianity spread to constitute the majority of Egypt's population. However, the Muslim Arab invasion brought Sunni Islam with a Cairo-based Islamic caliphate that remained in control for six centuries. After 600 years of Islamic ruling, Egypt continued to carry its Islamic identity through a Turkish Ottoman Empire lens. During those years, the indigenous population experienced a French invasion in 1798 led by Napoleon, which was dislodged by Ottoman Albanian commander Muhammad Ali, who eventually betrayed the Ottomans and seized Egypt for himself ("The Napoleonic Invasion of Egypt," n.d.; Bowman, 1989). 
During the final years of Muhammad Ali’s successors, Britain colonized Egypt, further exposing its people to additional modern Western identities. With Britain's presence, Ali's heirs remained symbolically in power while the British took control of Egypt's political affairs (Bowman, 1989). In 1919, backlashing at the British for exiling an Egyptian liberal revolutionary, Egyptians held mass demonstration demanding a parting from colonial and Ottoman occupation (Bisgaard-Church, 2011). The revolts concluded with Egypt's partial separation from the British and the first $19^{\text {th }}$ century Egyptian constitution, both giving Egyptians some ruling power. In 1952, due to growing discontent with the static power imbalances amid British, Ottomans, and Egyptian leaders, a famed military-driven coup called for the independent republic of Egypt (Cook, 2011). The achievement of full independence was dubbed in mainstream modern-day Egyptian perspective as Egypt's return to its rightful heirs (The pharaohs). This modern day view sketched a continuous lineage between the pharaohs and contemporary Egyptians as legatees of Egypt. Moreover, it termed the intermediate ruling period, between Pharaoh Egypt and The Republic of Egypt, as a period of unwelcomed foreign rule, while granting the military the mantle of protecting hero.

Yet much to the people's disbelief, in the years that followed, Egypt witnessed a long drawn-out toggling of power amid its authoritarian and highly privileged military representatives. Additionally, the country experienced deteriorating economic, healthcare, and educational systems, due to multi-level corruption and an incompetent workforce fueled by the military's will to dominate. This prompted a desperate need for change, which was already neighboring in motion with a Tunisian revolution against its own dictating regime. Thus, inspired by the Tunisian movement, Egyptians held mass 
demonstration in January 2011 against military President Hosni Mubarak demanding his removal, a change to the constitution, along with changes to several other governing laws.

This historical context provides an opportunity to explain why the period between 2011 and 2014 warrants exploration. In doing so, I will revert to the title of this thesis, which is Competing Narratives: The Struggle for the Soul of Egypt. Here, I want to emphasize that what I mean by "soul" is reference to an imagined unquestionable Egyptian national identity; it is a national identity that is unceasing historically and supposed to be universally accepted by all Egyptians. Next, I want to emphasize that what I mean by narratives are the collection of certain ideas, metaphors, stories, and symbols communicated by specific individuals to steer public opinion towards a particular definition of Egypt's soul; Egypt's alleged undisputed and continuous national identity.

Hence, what makes the years between 2011 and 2014 a unique period in Egyptian history was that it gave rise to an opportunity to launch a national debate around the future Egyptian national identity, particularly, a debate undisrupted by the influences of foreign rule and military power. As such, the void within the political arena, which was once filled by conquerors and afterwards by the military, triggered many narratives to redefine a presumed diachronic Egyptian national identity that likewise drafts Egypt's political future. However, because there were multiple supposed versions of a diachronic Egyptian national identity, the political arena became a battle zone of intense arguments and violent outbreaks for debating which version is accurate through multiple governing vehicles, such as the outbreaks surrounding redrafting the Egyptian constitution. 
From my initial reviewing of the conflict, I embarked on my study knowing that the debates surrounding redrafting the constitution related to the debated determination of the true Egyptian National identity. I also sensed by witnessing the historical references within the communicative dynamic that the conflict would be difficult to understand without historical contextualization. On the other hand, I was unsure which identity version was accurate, and whether I would conclude by determining a true single Egyptian national identity. Nonetheless, from a conflict resolution perspective, arbitration was not a goal; deciding which identity version is worthy, rather a bonus if my analysis unearthed so. I was more concerned with questions surrounding the above destructive communicative dynamic.

My hypotheses to analyze this communicative dynamic rested on the idea that it would uncover the narrators' motive to influence the identity definition in a particular direction. In addition, I hypothesized that the analysis may reveal why the identity narratives varied to begin with, which may inevitably lead to which identity narrative is accurate. Another hypothesis suggested that an analysis of the communicative patterns could unearth why the contenders were unsuccessful at dialoging. Thus, since I was interested in investigating how these societal power relations are established and reinforced through language and history, I decided to use a form of Critical Discourse Analysis (CDA) called the Discourse Historical Approach (DHA) as my methodology in collecting and analyzing the communications between the involved narratives.

In Chapter 2 of this thesis, I offer a relevant literature review developed in accordance with the emerging themes from the communication excerpts I collected for the period between 2011 and 2014, and before 2011 for historical contextualization. In 
COMPETING NARRATIVES

the subsequent chapters, Chapter 3 explains the methodology for collecting and analyzing these communications, Chapter 4 provides examples of the comprehensive analysis and a discussion of these conversational exchanges, and Chapter 5 provides recommendations to the issues highlighted in the analysis that may place the Egyptian community on a path to peaceful resolution. 
Chapter 2

Literature Review

As described in the introduction, the focus of this study is on the analysis of communicational exchanges amid the groups involved in the Egyptian conflict between the period of 2011 and 2014. The present chapter focuses on a literature review produced in accordance with the emerging themes from the communicational exchanges selected for analysis. The overarching theme as described briefly in the introduction centers on the conflict groups' attempts to redefine Egyptian national identity. As such, an in-depth exploration of group identity theory and closely related literature was necessary, such as literature relating to how identities behave under conditions of conflict, and how they behave during colonial and post-colonial periods, given Egypt's history.

Moreover, I specifically looked at the impact of colonialism on political structures in post-colonial nation-states. Amongst those impacts, I reviewed literature on rising nationalism as reaction to colonialism in post-colonial nations, especially in the case of Egypt. I studied specific cases of emerging Egyptian nationalisms during and post-British colonization. I also studied the psychological impact of colonialism and learned how colonialism was a passageway for racial arrogance that inevitably produced feelings of inferiority within the Egyptian community. Correspondingly, I regarded literature about the several forms these feelings of inferiority express themselves in post-colonial nations. Not surprisingly, I found evidence connecting these feelings to arrogant behavior, combativeness, and exclusiveness, all of which are sustained by the narcissistic nature of nationalism. 
Moreover, I reviewed the impact of utilizing arrogant and nationalistic approaches on conflict, and their relation to violence and distrust. This assessment focused on understanding the process of polarization through the breakdown of communication and the creation of in-groups and out-groups. This review led me into further literature regarding the benefits of contact between divided communities, also known as contact theory. Finally, I studied the efficacies of positive dialogue and argumentative dialogue, and the importance of incorporating core elements in the process of designing dialogue for divided communities. In the next section, I go into each area of the literature in more detail, and briefly explain their applicability to Egypt's conflict.

\section{Social Identity Theory}

Beginning with a general understanding of the need for identity, many human need theorists assert that identity is a basic human need, it is a psychological sense of self that further extends to a sentiment of belonging (Rothman, 1997). People generally are comprised of multiple identities, racial, national, gender, and more. Kriesberg (2003) explains that while some of the characteristics that make up individual and group identities are assigned at birth, such as skin color, many are cultured as a result of ongoing varying lived experiences, such as language, beliefs, and nationality (Burton, 1990; Kriesberg; Rothman). Kriesberg therefore arrives at the conclusion that identity is rather fluid in nature and constantly changing, and adds:

Many identities... are not based on ascribed traits but on shared values, beliefs, or concerns, which are varyingly open to acquisition by choice.... This is also true for political ideologies, attachment to particular pieces of land, or practicing a particular way of life.... They can endure for generations or change with shifting situations. (paras. 10) 
Because of this fluidity, overtime, many aspects that make up individual identity end up assimilated by choice. Moreover, many of those traits extend to a membership in a larger group and by the same token an exclusion from another, a dynamic that otherwise can be viewed as in-group and out-group identity formation. For Egypt's conflict, it is crucial to understand the process by which these memberships materialize. Tajfel and Turner (1986) explain this process, an individual's affiliation with in-groups and outgroups, through three stages. The first is "social categorization," placing the "self," within a certain group; the second is "social identification," viewing the traits of members within that group as attuned to one's own; and the third is "social comparison," becoming impacted by the world's perceptions of the in-group and the out-group. Tajfel and Turner say that social comparison is pivotal to a positive uniqueness attributed to in-group members to safeguard social identity. Oppositely, mourning for in-group trials hinders group social identity. Kriesberg (2003) confirms the latter saying, "People feel injured when other persons sharing their identity are injured or killed. Sometimes people are even willing to sacrifice their individual lives to preserve their identity group" (p. 1).

These principles are extremely relevant to the historical contextualization of the events in Egypt between 2011 and 2014, and a core element of the conflict that is expanded on in the discussion section of this thesis. For example, in the years leading to the 1952 coup, a social urge to reform a national political identity was in order due to British and Ottoman presence. Yet, because of Egypt's historical cultural intermixing, at that time Egyptians comprised a melting pot of ideologies. Thus, various identity groups where formed through varying processes of social categorization, social identification, and social comparison. The categorization process was a result of Egyptians' varied lived 
experiences and interactions, and consequently, Egypt became a pool of ideologically conflicting identity groups. In the analysis section I present these identity groups and their role in the conflict. Then, I underline how injuries to a member of one group were magnified as injuries to the entire group, and used as a mechanism of disqualifying the perpetrating group from national inclusion. I also provide examples of such dynamic and its impact on communication between the groups. Moreover, I review how group supremacy was salient amongst all these groups, and used as a mechanism in the determination of Egyptian national identity. In the discussion section, I go into a more detailed historical description of the reality of how each of these identity groups was formed in order to explain the equivocality of Egyptian identity.

These principles license social identity theory as a far-reaching model in intergroup conflicts, especially in post-colonial related conflicts such as in the case of Egypt. Below, I review further literature regarding the formation process and behaviors of these conflicting identity groups more specifically in post-colonial nations.

\section{Identity, Colonialism, and Conflict}

The psychological impact resulting from identity-loss trauma in post-colonial Egypt is one extremely relevant component to the categorization process mentioned above. This relates to how the empire building eras and the Western colonial period affected Egyptians through the imposition of foreign rules and the rejection of cultural compromises, which in turn suppresses native identities (Emig \& Lindner, 2010; Kambysellis, 1997; Slemon, 1996; Slemon \& Tiffin, 1989; Bassett, 1994; Rodney, 1972). Foreign ideas manifested through compulsory teaching of novel religious beliefs, such as Romans teaching Egyptians Christianity and Arabs teaching them Islam, and merely due 
to the foreign presence through an unconscious adaptation of foreign cultural norms by the indigenous population. Both imposed and unconsciously absorbed aspects are the causes of novel manufactured identities that compensate for the pre-conquest lost identity (Emig \& Lindner, 2010; Kambysellis, 1997; Slemon \& Tiffin, 1989; Rodney, 1972).

To explain, Shao-po Hsieh (1997) defines post-colonial as "the need, in groups which have been victims of imperialism, to achieve an identity uncontaminated by Eurocentric concepts and images" (p. 1). Indeed, for Egyptians, the conditions that illegitimatized, interiorized, and endangered their identities led to the need for identity restoration through the formation of counter-nationalisms. Yet, Shao-po Hsieh's definition slightly varies in the case of Egypt since, ironically, the immensely diverse historical conquest provided the reference from which these identities formed (a notion I expand more on in the discussion).

Consequently, as diverse post-colonial narratives for novel identities emerged, intra-national group conflict emerged. In looking at how the basic mechanism of group conflict operates, Kriesberg (2003) states, "For an inter-group (e.g., racial, ethnic, or religious) conflict to occur, each side must believe the fight is between 'us' and 'them'" (p. 2), and as such, dissimilar Egyptian national identity groups antagonistically separated themselves from each other. Moreover, conflicts that relate to territory, such as defining national terrain, persist and immerse as part of the group's identity, which leads intractability (Burton, 1990; Kriesberg; Rothman, 1997). This dynamic was certainly reflected in the relationships between the conflicting identity groups in Egypt during the period between 2011 and 2014, as many exhibited a long-standing and nationally publicized rivalry with little promise or intention for resolution on the horizon. 


\section{Nationalism}

According to Kriesberg (2003), resolutions for such intractable group conflicts depend on the nature of the involved identities. Nationalistic degrees for example determine how inclusive or exclusive the involved identity groups are. On one hand, less nationalistic identities are inclusive identities and are predisposed to evade elongated encounters. On the other hand, hard-core nationalists who tend to view their group as majestic are far more exclusive and thus engage in elongated conflicts (Kriesberg, 2003). Kriesberg confirms the above by saying:

Two groups with ethno-nationalist identities and with attachment to some of the same land are prone to engage in an intractable conflict. However, a group with an ethno-nationalist identity may avoid an intractable conflict with a group that has identities emphasizing other worldly religious concerns. (p. 1)

Indeed, the intersection between colonialism and nationalism plays a vital role in explaining much of the unfolding conflicts in postcolonial countries in general. As mentioned, the power of industrialized Western nationalism is what led to the competitive colonization of African countries. In turn, these colonized societies reacted by creating a counter-nationalism, and this is certainly evident in the case of Egypt. Therefore, as part of understanding the communication between the groups in Egypt it is imperative to understand the parameters of nationalism, its power, and its ambiguity. Harry Anastasiou (2008) defines nationalism saying, "Nationalism carries a view of the nation that is absolute and sacred in value, monoethnic in nature, collectivist and narcissistic in mentality, conflictual in predisposition, and militant in its concept of defense and in its means of freedom" (153). As this view of the nation sets in, nationalists 
retreat into a "mythic world" (Anastasiou, 2003, p. 45), a concept at the core of the nationalists" mind-set that presumes a "divine election" (Cauthen, 2004, p. 20) and determines how nationalists view the world. Cauthen says:

Nationalism, as an ideological movement that seeks autonomy, unity and identity for a population deemed to be a nation, draws much of its passion, conviction and intensity from the belief in a national mission and destiny; and this belief in turn owes much to a powerful religious myth of ethnic election. (p. 25)

The mythical idea of being "chosen" lends an intoxicating agent for social solidarity, national coherence, and political mobilization (Cauthen, 2004). To be chosen is to be driven by a moral compulsion — ordained by ethnicity, history, and/or God — that sets out a calling to which all members of the community must respond. Moreover, failure to respond may invoke the possibility of eternal destruction or damnation. This myth structures how history is perceived; it puts forward the notion of a continuing historical narrative of the nation as descendants and heirs to the homeland (the State) of their ancestors, whom share a common fate (Cauthen, 2004; Anastasiou, 2003, pp. 4546). The myth of being chosen is then further safeguarded by other nationalist myths such as the superiority, inerrancy, and invincibility of the nation.

Moreover, the inflation of mythical beliefs, which is normally manifested through media and educational systems, lends the concept of the nation as the supreme value an effortlessly accepted sentiment. Additionally, symbols such as the national flag, national anthem, and national emblem represent a certain unity, history, and distinctiveness that fortifies this sentiment (Podeh, 2011).

Podeh (2011) explains:

Sociologically, the flag constitutes a 'summarising symbol'... such symbols sum up, express and represent in an emotionally powerful and relatively 
undifferentiated way what the system means to its participants...In more concrete terms, the roles of the flag in the modern era have been numerous. Firstly, it was used to 'evoke powerful emotions of identification with a group'... This explanation is largely based on Emile Durkheim's functionalist approach; in his opinion, the flag - much like the tribal totem - 'is the sign by which each clan distinguishes itself from the others, the visible mark of its personality'...Therefore, the flag is a symbol that allows individuals to express their loyalty and allegiance to their group (nation), thereby strengthening the solidarity among its members and at the same time distinguishing it from other groups (nations)...In addition, the authoritative and sacred way in which the flag is activated on ceremonial occasions serves to strengthen the bond between members of the polity and that specific territory called homeland. The sacred meaning attached to the flag through the use of fixed and repetitive liturgy... is akin to performing a religious ritual...This 'cult of the flag' evokes powerful emotional reactions and in some cases even leads to self-sacrifice. (p. 422)

These divine attributions to the nation-state lead to fragmentations in the nationalist understanding of reality. The nationalist version of the nation's history or example becomes one of diachronic nature, a history that connects the nation's past, present, and future, a continuum of a legacy. The highlights of that history are the nation's triumphs in wars and revolutions and its great accomplishments. With this in mind, the construction of the nationalist rhetoric and its power to mobilize is created. Levinger and Lytle (2001) explain this mobilization rhetoric saying:

Virtually all rhetoric of national mobilisation contains three juxtaposed elements...These three elements are framed within a series of binary oppositions, contrasting the vision of an ideal past or future with the degraded present. The project of national rebirth represents an inversion of the existing disordered condition and a reconstitution of the ideal community. These binary oppositions fuse in the form of a triad. (p. 178)

This triadic construction of comparing the idealized glorious past to the degraded present is used to establish a standard utopian future to be reached and endorses the mechanism of how nationalists call for mobilization and the enhancement of national armed forces (Levinger \& Lytle, 2011). 
The mobilization rhetoric acquires nationalism the capacity to muster citizens into deadly movements while attributing loss of life to heroism and moral duty. This is especially problematic within ethnically diverse nation-states, where if specific ideologies are attributed to national identity, other identity groups suffer by becoming the outcast. Questionable nationalist practices such as ethnic cleansing for example seek to create an ideal community within a utopian future by restoring a presumed lost and glorious past. This past, according to the nationalist mind, is only achievable through a reversal of the circumstances that have tainted the present-day community. The monoethnic identity of the nation as defined by ethnocentric nationalism inevitably suppresses diversity within society, viewing it as problematic and unacceptable (Anastasiou, 2008; Dingley, 2011).

\section{Nasserism}

The above lends a strong elucidation as to why Egypt's 2011 conflict groups would strive to define a single identity for Egypt. Yet, it is important to understand that these nationalistic definitions pre-date the 2011 conflict. To exemplify, one of the many forms of Egyptian secular nationalism is Nasserism, a nationalist political ideology founded and led by Gamal Abdel Nasser, Egypt's second president and a leader in the Egyptian revolution of 1952. Though aware of Egypt's Islamic and Christian identities, Nasserism was a secular Pan-Arab ideology that utilized a form of socialism labeled "Arab socialism," promoting modernization and industrial development. Nasserism also encompassed components of republicanism, anti-imperialism, and transnational nonalignment, and hence, it opposed both Western capitalism and communism on the basis that they were incompatible with Arab customs (Ajami, 1974; Podeh \& Winckler, 2004). Nasser also viewed Zionism as an extension of European colonialism on Arab territory, 
yet he was against Islamic groups who shared the same feeling toward Zionism but clashed with his secular ideology (Ajami, 1974; Mansfield, 1973; Podeh \& Winckler, 2004; "Nasserism," n.d.).

Seen as an overthrow to colonial Western influences, the Suez Canal nationalization by Nasser in 1956 validated Nasserism and motivated its members to expand the ideology beyond Egyptian borders. The ideology hence affected other parts of the developing world, particularly with respect to anti-imperialism. Hugo Chávez, the late president of Venezuela, cited Nasserism as a direct influence on his own political thinking. Chávez spoke highly of the ex-Egyptian president saying:

Someone talked to me about his pessimism regarding the future of Arab nationalism. I told him that I was optimistic, because the ideas of Nasser are still alive... To say the least; I am a Nasserist, ever since I was a young soldier. (Nasserism," n.d., p. 3)

Additionally, British politician George Galloway glorified Nasser as "one of the greatest men of the 20th Century" (Nasserism," n.d., p. 3) and has encouraged Arab governments to hold the beliefs of his ideology (Ajami, 1974; Podeh \& Winckler, 2004; Nasserism," n.d., p. 3).

In the later years however, The Arab defeat in the Six-Day War of 1967 injured Nasserism as a protective national ideology. Hence, Nasser's successor, Anwar Sadat, abandoned certain aspects of Nasserism during what he labeled the "Corrective Revolution", but endorsed its pan-Arab component. Later, under the three-decade ruling of Sadat's beneficiary Hosni Mubarak, Pan-Arabism continued to thrive, but Nasserism as a whole was confined to writers, intellectuals, and opposition parties (Shehadi \& Mills, 1988; Sheikh, 2003). During the 2011 Egyptian conflict, the Karama Party of Nasserist 
Hamdeen Sabahi styled itself as the successor to Nasser and contended in the 2012 Egyptian presidential elections. However, present-day Nasserists, with their advertised support for democracy, human rights, and equality, market the ideology as less authoritarian than during Nasser's period, and explain Nasser's autocratic approach as necessary to execute his revolutionary actions (Podeh \& Winckler, 2004).

There is more than one example of Egyptian counter nationalism that formed around the early 1900s, such as pan-Islamism and liberalism influenced nationalisms, all of which are explained in more detail in the discussion section and how they relate to the impasses of 2011.

\section{Arrogance, Violence, and Distrust}

Counter-nationalism was one of two relevant postcolonial products in Egypt that are vital to highlight for the purpose of this thesis. The other significant product of the aggressive pursuit of intercontinental colonies is reflected in the psychological burden on the indigenous identity. Colonization for instance allowed for the emergence of ethnic superiority, where the conqueror obtained privileges over the indigenous majority. It denied the conquered people the capability for both self-rule and self-growth. Colonialism was also a passageway of showing racial arrogance, demeaning leaders and their people while encouraging rivalry and competition. As Fisher and Sharp (2004) explain, individuals conceal these feelings of inferiority and compensate for them by projecting insuperability, and thus, a natural disposition toward arrogant conduct is conceived.

The failure of post-colonial Egyptian society to utilize dialogical ventures as a means of conflict resolution, both on the interpersonal and the political levels, is partly 
attributed to the inclination toward arrogant behaviors. Arrogance evokes a pro-debate, competitive and inerrant orientation, and as result, hinders the ability of accepting other truths. Moreover, the nationalistic mentality, in which one's own version of nationhood and statehood surpasses any other version, indeed sustains and reinforces post-colonial arrogance.

If arrogance as a mechanism of concealing inferiority fails, individuals move to the other layers of pride preservation and gaining power, such as name-calling and violence (Fisher \& Sharp, 2004). This notion clearly played out in the Egyptian conflict between 2011 and 2014 by evidence of dialogues converting to settings of exchanged insults, and in some cases physical clashes that led to further violence amid supporters of each side. This contributes to a conflict's escalation and the eventual outcome of utter mistrust. The level of distrust depends on the number of violations and the perception of the victim in relation to the intention of the offender. Lewicki and Tomlinson (2003) say:

Distrust is the confident expectation that another individual's motives, intentions, and behaviors are sinister and harmful to one's own interests. In interdependent relationships, this often entails a sense of fear and anticipation of discomfort or danger. Distrust naturally prompts us to take steps that reduce our vulnerability in an attempt to protect our interests. Accordingly, our distrust of others is likely to evoke a competitive (as opposed to cooperative) orientation that stimulates and exacerbates conflict. (paras. 1)

In the analysis section I show how repeated clashes amid the rising counter nationalisms in Egypt has led to distrust, which plays a central role in dialogical failures even if one side attempts in good faith to rebuild relations. This is because once conceived, distrust formulates a prevailing framework on successive events in the relationship between the parties of conflict in such a way that "even good faith efforts by the offender to restore the relationship are met with skepticism and suspicion" (Lewicki 
\& Tomlinson, 2003, p. 1). Furthermore, the upshot of constant cynicism is a selffulfilling anticipation, parties react violently to each other merely based on suspicion, which in turn translates to the victimized side as further proof of warranted distrust (Lewicki, McAllister, \& Beis, 1998; Lewicki \& Tomlinson, 2003; Rousseau, Sitkin, Burt, \& Camerer, 1998).

\section{Competition, Collaboration, and Communication}

The problem with clashing forms of nationalism and arrogance within postcolonial countries is that they increase the chances of communal disagreements that lead to distrust. Additionally, the recurring manners in which parties approach these disagreements are central to fostering either a coexisting or a polarizing environment. Deutsch \& Coleman (2000) relay that most situations of disagreement have a mix of both competition and cooperation. Perceptibly, nationalism and arrogance push parties more towards a competitive approach to most disputes, and hence overtime promote a polarizing environment. However, there are also certain other dynamics that lead parties to utilize either competition or cooperation, which if understood may hint towards vital angles for trust building, a deconstruction of both nationalism and arrogance, and eventually positive contact.

Deutsch's theory of competition and cooperation rests on two basic ideas: The first relates to the interdependency of the positive and negative goals of the parties involved, and the second relates to the type of actions taken by the involved parties. Positive goals are goals that, if achieved, benefit both sides, and negative goals are goals that, if achieved by one side, result in an obstruction to the other side's goals. Deutsch highlights that if the goals of two individuals or groups are completely independent of 
one another, no conflict arises; therefore, the existence of a conflict implies some form of goal interdependency (Deutsch \& Coleman, 2000). Positive interdependence can be a result of people's cultural jive or need to overcome joint difficulties, and the opposite is true vis-à-vis negative interdependence. Deutsch explains that irregularities may occur in the level of goal interdependence; what side A does may have a considerable effect on side B, but what side B does may have little impact on side A. Thus, this power dynamic becomes key in handling disagreements (Deutsch \& Coleman, 2000).

Moreover, the types of actions taken by the involved parties fall into two types: “effective" and "bungling" actions (Deutsch, 2001, p. 77). Effective actions are the ones that improve one side's chances of attaining its goal, and bungling actions are the ones that worsen one side's chances of attaining its goal. Depending on the context of the relationship, individuals may choose to aid the other side's effective actions or to be satisfied with the other sides bundling actions. For instance, if one side views the effective actions by the other side as beneficial to its goals; they are likely to aid the other side in doing those actions. Similarly, if one side views the other side's bungling action as harmful to its own goals, they are likely to aid the other side in avoiding those bundling actions.

Effective and bungling actions affect three main areas—-substitutability, attitudes, and inducibility — that are the deciding factor of whether parties approach conflict cooperatively or competitively. Substitutability is how one party's actions satisfy another party's intentions; it licenses individuals to acknowledge the activities of others in fulfilling their needs. Thus, negative substitutability involves active efforts to counter the activities of opposing parties. Attitudes refer to the predisposed outlook of the involved 
parties to respond to aspects of their environment, either favorably or unfavorably.

Inducibility is the readiness to accept the other parties' influences, whereas negative inducibility refers to the readiness to obstruct what others want. Substitutability, attitudes, and inducibility are vital to the breakdown of the social and mental discourses involved in casting the effects of cooperation and competition (Deutsch, 2001).

Group conflict theory is another way of explaining Deutsch's positive and negative goal dynamic. It rests on the premise of competition over scarce resources and not human nature. To exemplify, an experiment at a children summer camp divided children into two groups competing over scarce resources, which resulted in fistfights among the children, who initially showed no signs of animosity against each other. Experimentalists decided to re-create goals that were captivating to members of the two groups but could not be attained by the resources and energies of either group independently. These goals, known as "superordinate goals" (Nadler, Malloy, \& Fisher, 2008, p. 472), caused the animosity to disappear and developed friendships amid the children (Nadler et al., 2008).

The tit-for-tat strategy is another example of the interdependency of goals between conflicting parties. Experts simulated a situation in which one side highlights the benefit of cooperation on both sides' positive goals by acting cooperatively, and thereafter encourages the other side to copy their move (Poundstone, 1992). The tit-fortat strategy shows that either side can stimulate its opponent to act competitively or cooperatively depending on how they behave when it is their turn to act.

One key factor then in the positive and negative goal dynamic is the conflict parties' view of possible outcomes for their disagreement. A zero-sum mentality - a loser 
and a winner outcome vs. a win-win outcome - is an approach that constitutes a competitive nature for each party to reach its goals. This mentality obviously is sustained by both nationalism and arrogance. Coleman and Deutsch (2015) explain that as competition takes conflicts towards damaging paths, they perpetuate by "autistic hostility" (p. 42), a self-propagating psychological process caused by a communication shutdown and misinterpretations. This pushes conflict parties into fabricated assumptions about each other that are in the end embodied by comparable actions - a process of selffulfilling prophecies as mentioned above. As a result, the creation of evil images begins to form on both sides of the conflict, and in return, disarmament becomes difficult without a feeling of venerability (Deutsch \& Coleman, 2000).

On this distressed communication, Anastasiou (2007) posits that suspicion codes information through the viewpoint of concealed motives, shaped in terms of intentions and less in terms of subject. With deepening mistrust, the situation begins to make exchanges that increasingly separate, and if tumbled into violence, the parties then slip into flawed perceptions, as pain becomes the primary reference for facts (Anastasiou, 2007). As both sides are alienated, the sole experience that they have of each other becomes the sum of incidences of hostility, and the profound meaning that violence communicates replaces all messages by false assumptions. Over time, this leads each side to demonize the "enemy other," which licenses killing. Propaganda becomes the only reality that affirms moral rightness, and truth becomes contradictory; one side's hero is the other side's villain and vice versa (Anastasiou, 2007). 


\section{Contact Theory}

If however parties are able to visualize a win-win scenario, and hence utilize one of the collaborative tactics mentioned above, it may provide an opportunity for trust building. In turn, it may open the doors to possible effective dialogue that can aid in the deconstruction of both nationalism and arrogance. In contrast, an imagined win-win outcome triggers a realization of possible common interests and interdependent objectives (Deutsch \& Coleman, 2000). A constructive path that alienated conflict parties can take in order to begin differentiating negative motives from legitimate concerns are joint ventures that result in positive contact. These ventures may lead each side to face the fact that the enemies have also experienced agony. This increased affiliation washes away the discriminatory assumptions of conflict-accustomed knowledge, hence generating a new world of positive possibilities fostered by collaborative efforts (Anastasiou, 2007).

This intergroup contact hypothesis was initially developed by Gordon W. Allport in 1954 and expanded by many researchers. Known as Intergroup Contact Theory, the process has shown in some cases to reduce prejudice and promote integrated perspectives. The premise Allport states is that under opportune conditions if communication between in-groups and out-groups transpires, then participants are able to recognize diverse outlooks relating to their ways of life. A consequence of this new understanding is a diminishment of stereotyping issues, deleterious assumptions, and restrictive prejudices (Brown \& Hewstone, 2005).

However, in order for post-violence anxiety to decrease and familiarity to take its place, contact situations need to be recurrent, consistent, and long enough. Additionally, 
some scholars say that if the members of the two groups use this contact setting to exchange insults, argue with each other, resort to physical violence, and discriminate against each other, then contact will likely not reduce the conflict. To obtain the beneficial effects, the situation must include positive contact embedded in criteria that include equal status, common goals, intergroup cooperation, support of authorities, and personal interaction (Brown \& Hewstone, 2005). However, there are some scholars whom have argued that even heated argumentative forms of dialogue may be beneficial over no form of communication, something I explore briefly in the recommendation section of this thesis.

\section{Dialogue}

One form that embodies contact between conflicting parties is the engagement in positive dialogue. However, having a clear understanding of the term dialogue within the realm of conflict resolution is essential for both the facilitator and the participants. In transnational peace building, the word dialogue is often reciprocal with discussion, negotiation, and political discourse. In effort to distinguish dialogue within the conflict resolution context, Feller and Ryan (2012) highlight eight core traits in the makeup of an effective dialogical approach. These traits are coexistence, movement, encountering the “other," assumption, creativity and flexibility, sharing, holistic, and multigenerational (Feller \& Ryan, 2012).

Bar-Tal (2004) defines coexistence as "a state of mind shared by society members who recognize the rights of another group to exist peacefully as a legitimate, equal partner with whom disagreements have to be resolved in nonviolent ways" (p. 253). 
Coexistence as a trait of dialogue fits as a primary motive for human interaction. Feller and Ryan (2012) cite communication scholar Kenneth Burke and say that the motive for communication is the hope to be fully experienced and recognized by others; dialogue participants are deeply motivated because they want to be understood. Therefore, the desire for coexistence is always present, which provides facilitators with a natural desire to bring participants together.

While coexistence is the motivation for dialogue, the second trait of dialogue, movement, is the manifestation of its exercise. Movement can be literal in the sense that conflicting parties must walk onto an actual cross-country border or known physical spaces that divide two communities. Crisscrossing conflict lines leads to other figurative movements, such as movement by intermixing social interests, sharing histories and traditions, and creating an awareness of the fruitfulness of the experience.

Encountering is understood as a deliberate involvement by both parties in the specific agenda of bringing up the conflict. Participants suddenly find themselves with whom they identify as the enemy, and then are suddenly exposed to a dissimilar consideration for reality other than their own. This experience allows both sides to speak and fully hear about each other's ideologies, perceptions, and understandings of history, especially as they relate to the conflict. This opens possibilities for change, where the circumstances are viewed less through moral lenses and more through a "benefits all" lens (Feller \& Ryan, 2012).

On assumptions, Feller and Ryan (2012) cite Bohm's explanation that dialogue serves as a means to evaluate our perceptions in collaboration with others. Bohm refers to that practice metaphorically as though perceptions are suspended as clouds in front of 
participants so they could be critically evaluated with the help of others. Feller and Ryan say that Bohm identifies a special relationship between thinking and speech as central to dialogue; he recognizes that dialogue is fundamentally a practice of examining thought together - a process leading to new ways of thinking. Regarding creativity and flexibility, pedagogical professionals have long recognized the significance of creative arts as avenues to access challenging material. Moreover, psychologists claim that creative methods "allow the subconscious and the conscious mind to better communicate" (Feller and Ryan, 2012, p. 360). Modern neuroscience suggests that engaging in artistic practice allows the brain to change wave production, increasing flexibility; that is, the more individuals think creatively, the more flexibility the thinking has, which is a prerequisite for the ability to negotiate conflict (Feller and Ryan, 2012).

The last two traits, holistic and multigenerational, mean to think of dialogue happening on all generational and social levels of society. For effective dialogue to take place, actioners ought to consider casting a wider net even if that means dialing down the intensity on all levels rather than intensifying the experience on one level. The thinking process must be holistic. As Feller and Ryan (2012) state, "If you have a conflict, identify 24 points where you can do something. And better to do a little bit with all 24 , than one giant step with one of them" (p. 363). In other words, think of the conflict as an entire body that needs mobilization. In order for it to move forward, all components must improve, even if slightly. By checking all the components, the body moves forward as a whole. In contrast, by checking off only one component, even if improved to its maximum, the body as a whole stays immobilized. More so, immobilized components have tendencies to negatively influence repaired ones. That is to say, if one level of 
society is engaging in dialogue, for example, the top level, and grass roots are not, or one generation is and the other is not, then the level not engaging has the capacity to eradicate all accomplishments at the engaging level (Feller and Ryan, 2012). 
Chapter 3

Methodology

This thesis poses the question, how does communication between the narratives shaping the events in Egypt since the 2011 revolution elucidate Egypt's current state of affairs? Because the research question focuses on the communicative exchanges between the narratives involved in the 2011 conflict, I chose to engage in qualitative research that relied on vocal and textual excerpts exchanged amid the involved parties during the period between 2011 and 2014. While researching several methodologies, I discovered critical discourse analysis (CDA), which is an interdisciplinary approach to the study of discourse that views language as a form of social practice; how the diverse motives of social beings creates and alters the world that they live in (Fairclough, 2012; Koller, 2012). I was interested in a form of CDA that was recognized for investigating political identities through a historical lens, and as a result, I used the discourse historical approach (DHA) for my inquiry. I utilized the main elements of DHA (described below) — contextualization, critique, discursive strategies and triangulation (Wodak \& Boukala, 2015) to collect and analyze the communicative excerpts of the conflict actors.

\section{Contextualization}

The first element of the DHA, Contextualization, is reference to placing single communication within a large historical scope, and for that purpose, timelines were an exceptionally helpful tool in providing a visual aid for identifying cause-and-effect relationships between contemporary and historic events. I started by sketching a timeline for the events between 2011 and 2014 and titled it the "Conflict-Timeline". The events highlighted on the timeline represented moments during the conflict when conversations 
intensified, referred to as "flare points." A set of flare points clustered together then generated a list of different topics.

Emerging topics of contention included the Egyptian constitution, EgyptianIsraeli relations, decisions regarding election processes, disbarments on election candidates, and accusations surrounding violent clashes and human rights defilements. Yet, projecting that an inclusion of all the topics would dilute each individual topic, and in turn dilute the research as a whole, I decided to make a case for my thesis using only one topic: the constitution as an element of domestic policy. My decision to focus on the constitution related to two factors. First, it represented the most frequent topic of controversy, and second, arguments involving other topics appeared to have stemmed from quarrels regarding the constitution.

Furthermore, realizing that conversations related to the constitution within the conflict-timeline extend back into the Mubarak and pre-Mubarak eras, I created a second and third timeline. The second timeline, labeled the "Mubarak-Timeline," accounted for the Mubarak regime's formation and conclusion, and the third timeline, labeled the "Republic-Timeline," accounted for Egypt's partial independence from the British in 1920 and up until the beginning of the Mubarak era. The purpose was to capture additional flare points linked to the topic of the constitution in order to render a greater understanding to the conflict-timeline arguments.

\section{Critique}

The second element of the DHA, Critique, refers to the ability to allow an analysis that is far from the researcher's biases. This was essential, since as an Egyptian native I am most likely conditioned by one or more Egyptian national narrative. The use of 
critique aided me in selecting the communication excerpts for analysis while minimizing my own biases towards the speakers and their perspectives. I aimed at collecting excerpts that followed and contextualized the flow of the 2011-2014 discourse, yet ones that also fit certain criteria. First, I targeted excerpts reported by the speaker directly or reputable news sources, such as public speeches. Second, I made sure to the best of my knowledge that all the communications reported on behalf of a speaker had not been denied by the speaker, and if so, I excluded it from the analysis. Third, I read every communication paying less attention to the author's political ideological background, and with no particular intention other than it related to a view regarding the constitution. Forth, I utilized an Arabic-English translator to revise all Arabic communications in order to diminish the prejudices in my own translation and interpretation. Fifth, critique helped me step away from the arbitrator role, the role of identifying right from wrong. On the contrary, it helped me focus on asking why conflict actors believe what they say to be true.

Finally, I held presentations displaying some of the hypotheses and communication excerpts for a diverse group of students at Portland State University. Some of the students were native Egyptians, others were from the Middle East, and others were from the United States. This invited challenging questions and reflective discussions that have conveyed insider and outsider perspectives on the hypothesis and the interpretation of the communications selected for analysis. Generally, the observations and claims I was putting forward were not in a sense extremely controversial or radical. For example, proposing that one group dislikes or demonizes another group, or that they advocated a certain form of statehood, did not need more than 
COMPETING NARRATIVES

a few communications to prove, as they communicated it clearly and undeniably through each excerpt.

\section{Triangulation}

The third component of the DHA, Triangulation, as Wodak and Boukala (2015) describe, is a key principle of the DHA that "enables researchers to minimize "cherrypicking' due to its endeavor to work on the basis of a variety of genres, methods of analysis, theories and background information" (p. 93). Triangulation is the act of merging numerous intersecting research methods that complement and challenge each other in the study of a particular subject. This creates checks and balances to the upshot of each technique, attributing a truer account to the findings. Wodak (2000) explains that triangulation "attempts to transcend the pure linguistic dimension and to include more or less systematically the historical, political, sociological and/or psychological dimension in the analysis, theory and interpretation of a specific discursive occasion" (p. 5).

I utilized triangulation in the sense that I approached my analysis from a varying range of disciplinary perspectives. I selected dissertations, journals, books, and videos that focused on history, psychology, and economics, rather than purely conflict resolution, to be a part of my literature review and as an analysis lens. Thus, I was able to analyze the same communication from a range of viewpoints, psychology, body language, economics, historical relevance, and social literature.

Moreover, I used excerpts from communications and literature published subsequent to the Egyptian conflict of 2011, I also used publications dating before the conflict's instigation. This was done to include perspectives, specifically on the origins of the conflict, the origins of the conflict actors, and the behaviors of the parties involved, 
from individuals who had not yet witnessed the conflict. This allowed me to conclude that these pre-conflict behavioral depictions are untainted by futuristic agendas, which could be the case for current publications now that the conflict has occurred. This inclusion filtered out possibilities of authors reshaping past events to explain future events.

Lastly, the use of a mixture of text and video sources helped create a multilayered analysis. For example, video communication helped me reexamine textual communication, and textual communication helped me examine how publications report video communication. I also utilized the element of third party interpretation that I utilized as part of my researcher critique to add or revise the meaning of selected communication.

\section{Discursive Strategies (Topoi)}

The forth component of the DHA, Discursive Strategies, are processes that identify certain schemes employed by political speakers in order to convince their audience of the claims they put forward. Wodak and Boukala (2015) highlight three examples of those discursive strategies in the following:

Referential strategies which focus on membership categorization devices, such as biological, naturalizing and depersonalizing metaphors...in order to represent social actors and especially in-groups and out-groups; predicational strategies attribute negative or positive, stereotypical characteristics to social actors; and argumentation strategies through which positive and negative attributions are justified and legitimized. (pp. 93-94)

The main tool I focused on was the argumentation strategies (or topoi) employed because they were sufficient to establish the existence of the varying narratives and the nature of their relationships. Wodak and Boukala (2015) define topoi saying: 
... the concept of topos is salient in this context for the analysis of sometimes fallacious and sometimes reasonable arguments which are widely adopted in prejudiced and discriminatory discourses...Following the Aristotelian tradition, we approach topos (pl. topoi) as a rhetorical and dialectical scheme that offers the opportunity for a systematic in-depth analysis of different arguments and statements that represent the accepted knowledge - endoxon — and which are usually employed by orators or opponents to persuade their audience of the validity of their opinions. Topoi are thus defined as parts of argumentation which belong to the obligatory, either explicit or inferable, premises. As such they justify the transition from the argument or arguments to the conclusion (Kienpointner 1996, 562). Hence, a topos should be understood as a quasi 'elliptic' argument (an enthymeme), where the premise is followed by the conclusion without giving any explicit evidence, while taking the conclusion to confirm, and relate to, the presupposed endoxon. (p. 94)

Topoi also demonstrate imperative limitations in the discursive construction of identities, which are based on imagined and sometimes flawed perceptions of reality (a salient component in my study)(Wodak \& Boukala, 2015). Some examples of topos include the topos of threat, the topos of definition, and the topos of national responsibility, each of which is explained when used in the analysis.

The results from the analysis identified the conflict players' profiles and ideological backgrounds; their attempts to polarize and dehumanize each other; and elements of rigidity and nationalism. The emerging themes from the analysis were then used to draft an extensive and supporting literature review. These results were used to draft an analysis section that draws-upon my major claims along with the supporting excerpts and literature. Then, an in-depth interpretation of the root causes of the claims I put forth in the analysis are explored in a discussion section along with all historical supporting evidence. Conclusively, the analysis and the discussion helped formulate a thesis statement that is in essence an answer to the thesis research question, along with a recommendation section. 
Chapter 4

Analysis and Discussion

Before starting the analysis, it is vital to clarify that I do not claim to have captured all the voices and topics discussed during the events between 2011 and 2014 relating to the Egyptian conflict. As described above, my methodology allowed me to collect and analyze many excerpts relating to many topics using three different timelines. My selection for the excerpts represented in this analysis focuses on key groups that to my knowledge have influenced masses in one direction or another regarding a centerstage topic: rewriting the Egyptian constitution. Moreover, the excerpts I chose to highlight in the analysis below are merely strong examples of a larger pool of excerpts, some of which may add to my proposition (varying narratives attempting to reshape Egyptian identity through the constitution), or tell other stories about the conflict. After my study, I can strongly claim that while these stories may add other dimensions to the conflict, I believe they would not contradict the propositions I put forth.

Similarly, the examples of conflict actors I mention below are only popular models of many other similar figures that have encouraged the same rhetoric. Here, it is important to also highlight that while I present some conflict actors as capitalists, liberals, or Islamists, this does not necessarily mean they identify as such. In fact, some individuals presented in this thesis have on certain occasions identified with an ideology that contradicts my placement, such as hardcore secular nationalists supporting the military identifying as liberals, and hardcore religious nationalists identifying as democrats. Thus, it is important to clarify that my placement for individuals within 
certain narratives purely relies on their consistent views and actions on the issues relating to the constitution between 2011 and 2014.

This disclaimer represents some of the challenges to my research, the challenge to include all topics related to the conflict, and the challenge of a hasty generalization about the conflict actors' ideologies, which would conclude an extremely lengthy and perhaps misleading research. Instead, I want to explain that I suffice by providing models of what I believe to be the most effective excerpts, communicated by popular actors, regarding a prevalent topic of controversy that evidently convey my findings and their position during this particular period. Thus, I attempt to avert these challenges by acknowledging the complexity and the danger of enclosing certain individuals inevitably within one narrative so as to not mislead my readers.

With that in mind, in Egypt's 2011-2014 constitutional struggle, three narratives take the forefront; those narratives are the democratic, Islamist, and secular narratives (Each further described below). I refer to those narratives as "master-narratives," grand narratives that bundle multiple "sub-narratives" with parallel views on the constitution. To illustrate, the democratic narrative encompasses liberals, left-wing activists, and young revolutionaries; the Islamist narrative encompasses the Muslim Brotherhood, the Salafists, and Al-Azhar scholars or Sufis; and the secular narrative encompasses the military, capitalists, and Coptic Christians. This bundling method sheds light on the varying levels of rigidity within the alliances, and identifies intergroup and intragroup disagreements and connections that can cornerstone resolution propositions. In the following, I provide brief profiles of each master-narrative, an overview of the Egyptian 
constitutional history, and an account of the events between January 2011 and January 2014 in order to support the understanding of the propositions I will present.

\section{The Master-Narrative Profiles}

\section{The Secular Narrative}

The first sub-narrative in the secular master-narrative is the Egyptian military, which, according to an article of the Egyptian constitution, belongs to the people, and its duty is to preserve Egypt's security and territories ("Constitutional History of Egypt," n.d.). As provided for in most Egyptian constitutions, with the exception of the provisional 2011 constitution and the 2012 constitution, the supreme commander of the armed forces is the president of the republic. Since the revolution of 1952, Egypt's leaders - Gamal Abdel Nasser, Anwar Sadat, and Hosni Mubarak-were all ex-military officers (Lynch, 2013). An example of a military conflict actor is General Abdel Fattah Al-Sisi, who was head of Egypt's Military Intelligence and Reconnaissance Administration before the 2011 revolution, and became Egypt's fifth president in 2014 (“Egypt: Abdul Fattah al-Sisi Profile,” 2014).

The second sub-narrative in the secular master-narrative are the capitalists, who advocate for a militant state, approves the use of excessive force as a means of security, and adheres to a capitalist objective. An example of a capitalist conflict actor is journalist and writer Mustafa Bakri, who holds a graduate diploma in political, legal, and economic systems from an Egyptian university and is the editor in chief of the independent newspaper El-Aosboa. He also hosts a program, Facts and Secrets, on Sada el-Balad TV. He has published numerous books, such as The Army and the Revolution, The Army and 
the Muslim Brotherhood, The Fall of the Muslim Brotherhood, and Al-Sisi: The Way to

Restore the Egyptian State. Bakri may refer to himself as a democrat or a socialist, yet his reactions to the constitutional draft, along with his support for the military and the capitalist agenda, safely places him within the secular master-narrative for the purpose of this thesis.

The third sub-narrative in the secular master-narrative is the Coptic Christian community, which, while a religious group, corroborates with the military and secularism for fear of the Islamization of the state by groups such as the Muslim Brotherhood (Emirates Center Strategic Studies and Research, 2017). Its belief regarding its role, rights, and ties with Egypt rests within the introduction of Christianity in Egypt reflected in the historical narrative mentioned in the introduction. Key actors representing the Coptic community are Pope Shenouda III of the Coptic Orthodox Church of Alexandria, and Anba Morqos, the official representative of the church. Another example of a Coptic Christian figure is Egyptian billionaire businessperson Naguib Sawiris. He is the chairman of Weather Investments's parent company, and chairman of Orascom Telecom Media and Technology Holding S.A.E. and also serves on several Boards, committees and councils, as well as an extremely popular and VIP person in Egypt. Sawiris markets himself politically as liberal, yet, his views on particular elements of the constitution places him within the Coptic Christian sub-group, particularly because of the public's opinion of his views.

Key characteristics of the secular master-narrative include the separation between church and state, modernization, industrialization, concentration on Arab values rather than Muslim values, a hunger for economic dominance, negligence for human rights, and 
firm support for the military and national security. Most proponents of secularism emphasize the link between secularism and national unity, specifically between Coptic Christians and Muslims.

\section{The Islamic Narrative}

On the other hand, the first sub-narrative in the Islamists master-narrative is the Muslim Brotherhood (MB), which is a global Sunni Islamist organization with an identified aim to inculcate Sharia law (Islamic law) and the Sunnah (the ways of Islam's prophet Mohamed) as the basis for community and state affairs. Its mottos include "Islam is the solution" (Patel, 2007, p.127) and "Allah is our objective; the Qur'an is the Constitution; the Prophet is our leader; jihad is our way; death for the sake of Allah is our wish" (Ali, 2011). As a Pan-Islamic movement, it believes Islamic governments must eventually unify in a caliphate system and regain Islam's manifest destiny, an empire stretching from Spain to Indonesia. The Brotherhood is the most Islamic group involved in politics; it preaches that Islam will bring social justice and the eradication of poverty and corruption (Zeghal, 1999). A Brotherhood conflict actor is the Brotherhood's political party, the Freedom and Justice Party (FJP), and Mohamed Morsi, the party's lead spokesperson and presidential nominee in 2012.

The second sub-narrative in the Islamist master-narrative is the Salafists, which is an ultra-conservative movement within Sunni Islam. The movement takes its name from the Arabic term salaf, or "predecessors," identifying the earliest Muslims believed to provide the epitome of Islamic practice. A narration by the Prophet Muhammad praising the people of his own generation and the people of the succeeding two generations is viewed as a call to Muslims to follow the example of those first three generations known 
as the Salaf. The Salafi movement's conservatism is considered a less violent hybrid of Wahhabism and is therefore feared in Egypt (Osama bin Laden was a Wahhabist). While the majority of Salafists avoid politics and is more concerned with how laws restrict their abilities to practice Islam, some Salafi youths saw themselves as revolutionaries and chose actions ranging from militant jihadism to protest politics (Brown, 2011; Zeghal, 1999).

The third sub-narrative of the Islamist master-narrative is the Sufis, who are viewed as moderate diviners absorbed in spirituality rather than in politics. Sufism is not a distinct Islamic sect; it is a different focus of practicing Islam and is the default Muslim religious life in Egypt. The Sufi community spawns from Al-Azhar University, which, according to a 2011 report issued by the Carnegie Endowment for International Peace, is strongly Sufi in character (Brown, 2011; El-Houdaiby, 2012). In 1961, the selection of the university's Grand Sheik (leader) became a presidential appointee, who gave the Grand Sheik the responsibility for assigning graduates of Al-Azhar as leaders to all major mosques. Major mosque leaders hence became state employees who recognize its superiority and legitimize its policies, and only issue temperate edicts (fatwās) on disputes regarding religious Islamic practices in Egypt that parallels its political agendas. Consequently, vast portions of the self-governing Brotherhood and Salafists mosques view them goadingly as puppets of the status quo (Abu-Rabi', 1988; Albo, 2012; Brown, 2011; El-Houdaiby, 2012; Zeghal, 1999). A Sufi 2011 conflict actor is the Grand Sheik of Al-Azhar Mosque, Ahmed al-Tayeb.

\section{The Democratic Narrative}


For the Democratic Master narrative, it is important to highlight that there is a vast distinction between the definition of Middle Eastern democracy and western democracy. Meaning that while political individuals in Egypt may call themselves democratic, what that mainly entails is their desire for a non-religious and non-militant state. Yet, when it comes to human rights, environmental care, inclusiveness and equity, the level of attention and advocacy for those details is trivial in comparison to western democratic liberals and socialists. Most Egyptian democrats are fundamentalists for the same reasons when it comes to their tolerance of other beliefs and ideologies within Egypt.

With this preface, the first sub-narrative in the democratic master-narrative are the liberals, and because of the interchangeability and ambiguity between the terms liberal, socialist, and leftist in Egypt, I will suffice by giving examples of three conflict actors whom have identified as either. One example is former director general of the International Atomic Energy Agency (IAEA) and Nobel Peace Prize winner Dr. Mohamed ElBaradei. ElBaradei was born in Egypt and earned a bachelor's degree in law at the University of Cairo and a doctorate in international law at New York University School of Law. He launched his career in the Egyptian diplomatic service, serving in the Permanent Mission of Egypt to the United Nations in New York and Geneva, where he was in charge of political, legal, and arms control issues. From 1974 to 1978, Dr. ElBaradei was a special assistant to the foreign minister of Egypt and was a member of the negotiating team that led to the conclusion of the disengagement agreements between Egypt and Israel (International Atomic Energy Agency, n.d.). 
Another figure is Amr Hamzawy, who studied political science and

developmental studies in Cairo and Berlin. He was previously a senior associate in the Middle East program at the Carnegie Endowment for International Peace and the research director of the Carnegie Middle East Center in Beirut, Lebanon. He also served as faculty at the American University in Cairo, at Cairo University, and at Stanford University. His research, teaching, and academic publications about Egypt focus on democratization processes, civil society, and human rights and governance. Hamzawy is also a former member of the Egyptian National Council for Human Rights and contributes a weekly op-ed to the Egyptian independent newspaper Al-Shorouk (“Amr Hamzawy,” n.d.).

Writer Alaa al-Aswany is another figure representing the democratic masternarrative. Al-Aswany, the author of the Arab world's highest-selling book ever, The Yacoubian Building, is a reasoned but uncompromising critic of the Egyptian government and the religious extremists aligned against it, as well as Western leaders whose condemnation of oppressive dictatorships is too often inconsistently applied. AlAswany's World Affairs blog focuses on global and regional issues related to politics, security, and human rights. Al-Aswany speaks Arabic, English, French, and Spanish, and his work is published in 24 languages worldwide. He originally trained as a dentist and has a practice in Cairo, where he resides ("Alaa al-Aswany," n.d.).

The other sub-narrative in the democratic master-narrative is the group of young revolutionaries, such as the grassroots movement Tamarod, or "rebellion" ("Profile: Egypt's Tamarod Protest Movement," 2013). Ideologically, liberals/socialists/leftists and young revolutionaries fiercely advocate for a democratic state and social equality, and will just as much criticize the military and government corruption as they do the Islamists. 
They condemn use of excessive force and absolutism, thus placing a high value on human rights, parliamentarism, freedom of speech, and equal distribution of wealth, yet mostly in theory as mentioned above (Abdel Kouddous, 2013; Kirkpatrick \& Sheikh, 2012; Masoud \& Nawara, 2012).

\section{The Constitution}

The purpose of providing the conflict actors' profiles is to aid in the understanding of their position on the topic of contention, which is the constitution. Likewise, a brief understanding of the constitutional history of Egypt serves the same purpose. The constitutional history of Egypt dates back to when the Ottomans ruled Egypt, and due to their Islamic heritage, legislation remained drawn from the Holy Qur'an and the Sunnah of the Prophet Mohammed, or Islamic Sharia (Eldem, 2013). Influenced by modernity, the Kanun, or state "law," introduced an amalgamation of the Napoleonic Code, Roman law, and Islamic Sharia into Egypt's legal systems, which brought about the idea of a constitution separate from Sharia laws ("Legal Research Guide: Egypt," 2015).

It was not until the 1923 constitution that law recognized Egypt's Islamic identity (Gasper, 2009; Ghali, n.d.). After the 1952 military revolt, in 1956, a new constitution was announced calling for the formation of a National Assembly, and was changed twice, with the formation and secession of the Egyptian-Syrian merger. When president Anwar Sadat took office, he adopted the constitution of 1971, which included Article II, establishing the principles of Sharia as the source of legislation. In the years to follow, Egyptians would come to be ever more discontent with the constitutional reign of Hosni 
Mubarak, and in the 2000s, the president, the Muslim Brotherhood, and revolutionaries argued for multiple needed changes to the constitution. As a result, Mubarak requested parliament to amend Article LXXVI (76), which defines how the president of Egypt is elected, allowing for a multiparty election in 2005 (Cook, 2011).

Following Mubarak's resignation, the military proposed a new 2011 provisional constitution that paved the way for the 2011 parliamentary elections and the 2012 presidential election. The provisional constitution included the 4-year term and two-term service limitations for the elected president, replacing the 6-year indefinite term article in the pre-revolt version, and tasked the newly elected parliament with forming a new 100member constitutional drafting committee to write a permanent constitution for Egypt (“Egypt Referendum Strongly Backs Constitution Changes,” 2011).

In November 2012, the assembly approved a draft constitution, which Muslim Brotherhood president-elect Mohamed Morsi signed into law (“Egyptian Constitution 'Approved' in Referendum," 2012). After Morsi's ouster, the 2012 constitution was suspended and eventually replaced with the 2014 constitution. Under that constitution is a guarantee of equality between the sexes, absolute freedom of belief, and an acknowledgment of Islam as the state religion. It also included the 4-year term and twoterm service limitations for the elected president. Yet some argued that it bequeathed more power to the military than the 2011 revolutionaries had hoped for (International IDEA, 2016; “Official Vote Result,” 2014; “The 2014 Egyptian Constitution,” 2014).

The key learning from this overview is that the Egyptian constitution underwent multiple stages of modification. These modifications were marked by the scuffle between religious and secular laws, as in the many examples of including or excluding sharia law 
and Egypt's Islamic identity. During the 2011-2014 period, Egyptian political structure comprised of an executive (president's cabinet), a legislative (upper and lower house of parliament), and a judiciary (the district and supreme courts). Indeed, the tug of war between all these branches, along with the military, was a hallmark of the events between 2011 and 2014, which are accounted for below.

\section{Major Events between 2011-2014}

Beginning in January 2011, Egyptians held a revolt against military president Hosni Mubarak, who stepped down in February 2011 and turned his power over to the Supreme Council of the Armed Forces (SCAF). SCAF then dissolved the parliament, suspended the constitution (Associated Press, 2013), and drew up a 6-month rebirth plan of all government branches. It also planned for an amended provisional constitution that would set the stage for the subsequent parliamentary and presidential elections, and vowed to relinquish power to the elected government (Childress, 2013).

Yet, a controversy caught traction when some of Egypt's Coptic Christian intelligentsias and other political leaders suggested modifications to Article II of the constitution to include statements representing Christians in relation to their public affairs, or the article's deletion (Ding, 2011). The comments stirred arguments among the Islamists, who supported Article II, and the opposing democrats and seculars. SCAF, who were in favor of Article II, announced a provisional constitution in March 2011 that included Article II, and supporters of the Article cast an overpowering approval ballot securing its inclusion (Associated Press, 2013). This transitory constitution also tasked the upper and lower houses of parliament to elect a 100 -member commission to draft a new constitution (Childress, 2013). 
Later, parliamentary elections between November 2011 and February 2012 resulted in Islamists dominating $75 \%$ of the lower house and $90 \%$ of the upper house (Mostly Muslim Brotherhood and some Salafists), which eventually led to an Islamicaly dominated constitutional assembly (Associated Press, 2013; Childress, 2013). Democrats and seculars disputed the Islamist dominance in both chambers, triggering the judiciaries to place both chambers under review for probable disbandment. Nevertheless, with parliamentary and constitutional matters on the move, SCAF instigated the presidential election process between March 2012 and June 2012. Muslim Brotherhood candidate Mohamed Morsi and the last military prime minister under Mubarak Ahmed Shafiq emerged as front-runners. Shafiq's presence in the race stirred a united outrage on the Islamic and democratic fronts, prompting another intervention from the Supreme Courts. Two days before the presidential elections, in June 2012, the court ruled for the armybacked candidate to stay in the race, and for the dissolution of the lower house of parliament, angering both the Islamic and the democratic narratives. It also awarded SCAF control over the national budget and the power to issue laws, diluting the power of the forthcoming president (Childress, 2013).

Days later, Morsi won the presidential seat with $51.7 \%$ of the vote, becoming the first civilian president of Egypt. In August 2012, he ordered the retirement of the top Mubarak-era headship of the military and selected General Abdel Fattah Al-Sisi as his defense minister (Associated Press, 2013; Childress, 2013). In November 2012, members of the democratic and secular parties withdrew from the 100-member assembly, protesting against the lack of skill sets needed to draft a constitution, and against the attempts by Islamists to enforce their will (Associated Press, 2013). Later that month, 
Morsi broadcasted a constitutional statement granting him the power to rule exclusively without the right of other branches of government to veto (Childress, 2013). Furthermore, it granted him the right to use all required measures to defy threats against the January 25 revolution, specifying that no authority could dissolve the existing upper house of parliament or the constituent assembly (Sabry, 2012). Outraged, democrats and seculars formed an alliance, termed The National Rescue Front (NRF), to resist Morsi's declaration (Kortam, 2012).

In that same month, the constituent assembly finalized the constitutional draft, which Morsi approved and set its referendum for December 15, 2012 (Childress, 2013). Thousands of liberal and secular protestors marched to the presidential palace on December 4, 2012 demanding the cancellation of the referendum and a new constitutional draft, claiming that Islamists subjugated the current constitution language. On the same accord, the NRF demanded the annulment of Morsi's power sweeping decree, the withdrawal of the current constitutional draft, the postponement of the referendum, and the formation of a new constituent assembly. Morsi annulled the decree granting him unlimited power on December 8, 2012, yet rejected all other NRF demands, proclaiming that if the constitution did not pass, the public would revote 100 new members to write a new one, and then he asked the NRF to dialogue. The NRF rejected his dialoging offer and moved to sponsor weeks of demonstration after the draft passed the referendum with a $64 \%$ "yes" vote by a turnout of $32.9 \%$ of Egypt's 52 million eligible voters. Morsi signed it into law on December 26, 2012 to replace the 2011 provisional constitution (Associated Press, 2012b). 
Consequently, graffiti promoting "No" for the constitution of the Brotherhood juxtaposed "Islamic state" slogans by Brotherhood supporters' in the streets of Cairo. In January 2013, the NRF announced its decision to boycott the parliamentary elections called for by Morsi, and in turn, Egypt's courts canceled them (Kortam, 2013). Between January 2013 and April 2013, thousands held protests against Morsi that resulted in further tension between democratic and secular protestors and Brotherhood enthusiasts. One episode was the attack on a cathedral of the Coptic Orthodox Church during a funeral proceeding, which Pope Tawadros II blamed on Morsi's futile protection. The NRF then backed the launch of "Tamarod", a youth group founded to collect impeachment signatures and call for mass protests on June 30, 2013. Before that day, Tamarod announced it collected more than 22 million impeachment signatures, and on June 30, 2013, millions of protesters demonstrated, accusing the Brotherhood of hijacking Egypt's revolution and imposing Islamic law. Hundreds sailed through the Nile chanting against Morsi, while thousands backing Morsi congregated in Rabaa Square chanting Islamic sentiments. Clashes around the MB headquarters resulted in its raiding and eight deaths (Childress, 2013).

Tamarod offered Morsi until July 2 to resign, and Al-Sisi, as Defense minister, threatened to intervene if the dispute was not resolved by July 3 (Childress, 2013). As the deadline loomed, multiple government officials resigned, leaving the government with only members of the FJP (Al-Youm, 2013a). On July 3, 2013, Morsi rejected Al-Sisi's 48-hour ultimatum, resulting in his arrest and placement under military custody. AlAhram newspaper reported, "The Egyptian police had been ordered to arrest more than 300 members of the Brotherhood and issued travel bans on all its members" (Spencer, 
2013). Immediately, the Chief justice was appointed as interim president, the upper house was dissolved, and the constitution was suspended ("Egypt Crisis," 2013).

The Brotherhood termed the happening as a "military coup," and some Islamists threatened armed retaliation (Wedeman, Sayah, \& Carter, 2013), yet some Salafists and most Sufis sided with the military's decision to remove Morsi from his position. Between July 2013, and August 2013, supporters and challengers clashed at multiple venues. Brotherhood supporters protesting where witnessed by BBC news reporter Jeremy Bowen being fired at with live ammunition, resulting in 51 killings and 435 injuries ("Egypt Unrest," 2013). The army clashed again with Brotherhood protesters at the Republican Guard compound, claiming that terrorists tried to storm it, resulting in more than 300 tragedies that a Brotherhood member described as a "massacre" during dawn prayers (Dziadosz \& Nasralla, 2013) (“Massacre in Cairo Deepens Egypt Crisis,” 2013). At the same time, Morsi supporters forced two soldiers to make pro-Morsi statements while filming them being beaten (AFP, 2013).

The divide made Egypt's Christian minority a target; churches across Egypt canceled their evening social activities. Two days after the ousting, mobs rampaged through a Christian village, burning dozens of homes, ransacking stores, and stabbing four people to death. In a coastal city, masked gunmen opened fire at a local church and killed a Coptic pastor in an outdoor market (Childress, 2013; Hendawi, 2013). On August 14, 2013, the violence would come to rise steeply when Egyptian security forces raided two pro-Morsi camps in Cairo: one at al-Nahda Square and a larger one at Rabaa alAdawiya Mosque. The camps were plundered and cleared in hours after attempts to end the six-week sit-ins failed. Tents and bodies were on fire, and the main mosque of Rabaa 
Al-Adawiya was burned with hundreds of unidentified bodies inside. According to the Egyptian Health Ministry, 638 people were killed, of which 595 were civilians and 43 were police officers, with at least 3,994 injured. The incident and its aftermath make the sum of fatalities the highest since the 2011 revolution that toppled Mubarak (Childress, 2013; “Death Toll from Egypt Violence Rises to 638," 2013; Mohsen, 2013).

Violent retaliations followed in several cities across the country, extending to September 2013 when Egypt's minister of the interior survived a suicide car bomb (Childress, 2013). In that same month, the courts banned the Muslim Brotherhood from all political activity, and in November 2013, sanctioned all forms of public protest without court permission. In December 2013, following a police station bombing, the Muslim Brotherhood was declared a terrorist organization. In January 2014, Egypt voted on a new constitution drafted by the interim government that passed with $98 \%$ of the vote, with $40 \%$ of Egypt's voting population partaking. In June 2014, protests would come to fade as Egypt elected its fifth president, former military general Abdel Fattah al-Sisi (“The Egyptian Revolution,” n.d.).

\section{The Analysis}

Coming to my first claim, the analysis of the communications between the three master-narratives reveals that they are competing to accomplish two main goals through the constitutional battle. One, each narrative is attempting to normalize their views on statehood as desired and accepted by all members of Egyptian society; and two, each narrative is attempting to polarize the other narratives' views on statehood up to the point of demonization to justify violently eradicating them. The three master-narratives accomplish both these goals by utilizing a variety of discursive strategies (see Chapter 3) 
to communicate their views on constitutional amendments, parliamentary elections,

constitution assembly members, and presidential elections. In the following, I will shed

light on examples of these discursive strategies in three main areas, each master-

narrative's aspirations for statehood, each master-narratives criticism for the other

narratives' aspirations and polarizing attempts, and each master-narrative's demonization

and violence validation.

\section{Aspirations for Statehood}

On the democratic master-narrative side, after Mubarak's ousting, liberal college

professor and political activist Amr Hamzawy (2011a) said:

I have attempted to intensify discussion on a range of issues: whether a presidential or a parliamentary regime is more preferable for a democratic Egypt; amending the current constitution versus drafting a new one; the role of the military in the transitional stage and afterward; how to institutionally manage an expanded national dialogue about the transitional and democratic stage....All these issues are more central and important to Egypt's democratic transformation than the discussion of the identities of possible candidates.... My bias here... is in favor of a parliamentary republic that guarantees developed political life and limits the encroachment of the presidency and executive authority. I prefer this to a presidential republic that gives the president absolute power with no accountability. I believe strongly in the necessity of a new Egyptian constitution that establishes parliamentarianism and saves us from the flawed 1971 constitution.... I also think it preferable that, after the Supreme Council of the Armed Forces hands over rule to an elected parliament and president, the role of the military in political life be retained...to guarantee that there will be no coup against democracy and pluralism... one must take note of the respected stance of Mohammad ElBaradei, who refused to talk personally about his potential candidacy and continually stressed the importance of achieving constitutional, political, and institutional reform before thinking about the identity of presidential candidates. He then announced that he would not run for the presidency, affirming that what concerned him was Egypt's democratic transformation. (paras. 7-10)

In this communication, Hamzawy demonstrates the mainstream aspiration for statehood advocated by the democratic narrative by saluting ElBaradei's support of Egypt's democratic makeover. He clearly voices opinions on statehood when he 
advocates for "parliamentarianism," a liberal democratic governing structure. He also voices opinions about the previous constitution and regime (the secular master-narrative) when he says, "Absolute power with no accountability," and subtly warns, using the topos of threat, which states that if there are specific dangers one should act against them (Wodak \& Boukala, 2015), from the possibility of other non-democratic groups, namely the military, hijacking the revolution. This warning manifests in the phrases "the role of the military in political life be retained..." and "coup against democracy." In furthering the democratic narrative's position on statehood, he said the following in response to the provisional constitution that was finalized by SCAF in 2011:

The amendment to Egypt's constitution recently announced by Chancellor Tareq Bishri's commission - if adopted by the Supreme Council of the Armed Forces and approved by a majority of citizens in a general referendum - will lay the foundation for constraining the near-absolute powers granted to the president by the 1971 constitution....Despite these proposed amendments, the 1971 constitution supports an authoritarian system of government that gives too much control to the president, violates the powers of the legislative and judicial branches, and suspends citizens' liberties and rights. It is therefore unsuitable for managing a safe transition to democracy, which requires a parliamentary constitution and balanced powers among all three branches of government - along with strong mechanisms of inter-branch oversight and accountability. Amending the current constitution is not enough, but these proposed amendments help ensure that a new constitution will be written for a free democratic Egypt after the legislative elections. (Hamzawy, 2011b, paras. 1, 10, 11)

Here Hamzawy again criticizes the 1971 constitution and stresses the importance of the new constitution's correlation with a democratic Egypt. His statements demonstrate his deep knowledge of political systems and passion for democratic structures both funded by his education, occupation, and activism (see profiles). His warnings in this communication clarify a predisposed loathing and skepticism amid the democratic master-narrative toward the secular master-narrative. 
On the Islamic master-narrative side, aspirations for statehood for the three subnarratives were evident when they collectively condemned any alterations to Article II of the constitution. The Salafists hurled a massive campaign to collect signatures, stressing the need to hold on to the article, and then promoted the campaign on Facebook (at www.facebook.com/IslamicId). The campaign coordinator described it as a "pre-emptive move designed to emphasize the Islamic identity of Egypt and insure it will not be touched [tampered with] and as pre-empt calls for the suppression of any campaigns attempted to remove it from the new constitution" (Mourad, 2011, para. 7, translated from Arabic ${ }^{1}$ ). The Salafists' concerns however mainly related to how Islam is practiced in Egypt, and thus theorize that an Islamic Identity verses a secular identity would insure the proper mechanisms for Islamic practice. For example, many Salafists echoed a similar sentiment to the content of a popular flier distributed in Cairo by a group named the Egyptian Revolution Society. The flier read:

The problem is that our country will be without a religion... This means that the call to the prayer will not be heard anymore like in the case of Switzerland, women will be banned from wearing the hijab like in the case of France... And there will be laws that allow men to get married to men and women to get married to women like in the case of America. (Slackman, 2011, paras. 17).

On the Sufi side, as summarized in the "Post-Mubarak Era Public Debates" article, the Grand Sheikh of Al-Azhar, Ahmed al-Tayeb, announced his rejection of all alternations to the article, describing it as an "established principle for the state" ("PostMubarak Era Public Debates," n.d., para. 2). Al-Tayeb added that changing it may "provoke sedition" ("Post-Mubarak Era Public Debates,” n.d., para. 2), establishing that "Article II is one of the pillars of the state and nation, and that talk of changing the article

"خطوة استباقية تهدف الى التأكبد على هوية مصر الاسلامية وعدم المساس بها واجهاض الدعوات لالغائها من أي دستور جديد" 1 
raises sectarian tensions, and sectarian tensions are threatening to freedom and democracy” ("Post-Mubarak Era Public Debates," n.d., para. 2). He also said that any alterations would disturb Egypt's Islamic identity but further made it a point to explain that he was not denoting the "theocratic religious sense of an Islamic identity" ("Azhar Grand Sheikh Again Rejects,”2013, para. 5). This means that while al-Tayeb values Egypt's Islamic identity in principle, his concerns relate less to practice and more to stability and security.

On the far end of the Islamic narrative, the Muslim Brotherhood (MB), who strategically sided with protestors to annul religious attributions to the revolution, clearly represented the main opposition to the other two master-narratives. During the 2011 protests for example, Mohamed Morsi said, "We are not pushing this movement, but we are moving with it. We don't wish to lead it but we want to be part of it" (Yassin-Kassab, 2011, para. 1). The MB advised against any alternations to Article II, and their approval for the provisional constitution of 2011 that included the Article was mentioned in the following:

The group supports the amendments approved by the committee, which is headed by Judge Tariq human. He [Mohammed Morsi] calls on to the nation to approve them, as a 'first step towards the path' and 'closest to the right path.' $\mathrm{He}$ [Mohammed Morsi] adds that although it 'is not sufficient to satisfy the demands of the revolution and the revolutionaries, but that the country is at a critical stage that requires it to get out of the bottleneck through those amendments that leads us to a state of stability.' (Sarhan, 2011, translated from Arabic ${ }^{2}$ )

Yet, even though the group's initial stand shed away from a direct unveiling of their aspirations for statehood, members of the Brotherhood were notorious for their

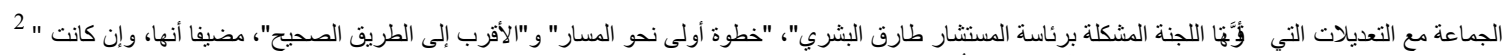

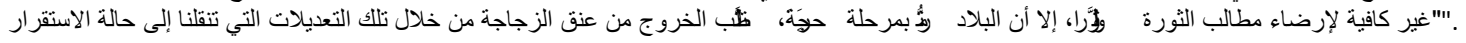


Islamist political ambitions for many years. Most recent to the 2011 revolution was via

their 2004 political platform mentioned by liberal Magdy Khalil (2006) in the following:

The Muslim Brotherhood issued a March 2004 political platform, which was in fact a proposal for an Islamist state. According to this initiative: "Our mission is to implement a comprehensive reform in order to uphold God's law in secular as well as religious matters.... Our only hope, if we wish to achieve any type of progress, is to adhere to our religion, as we used to, and to apply the Shari'a (Islamic law)." It states that the Brotherhood's "mission is to build a Muslim individual, a Muslim family and an Islamic rule to lead other Islamic states." How would this Islamic identity affect the media, economy, politics, education, social welfare, women's issues, and culture? The Muslim Brotherhood elaborates on these issues in its initiative: "The Media should be cleansed of anything that disagrees with the decrees of Islam." "We believe in an economic system that is derived from Islam.”..."The focus of education should be on learning the Quran by heart."..."Women should only hold the kind of posts that would preserve their virtue." ..."There should be a ban on improper and offensive series and television programs." (para. 14)

More clues for the Brotherhood's desire for statehood were apparent when they contradicted their initial stance on not leading the revolution by entering the race for parliamentary and presidential elections. Additionally, while their initial campaign did not include religious slogans ("Brotherhood begins campaigning without religious slogan”, 2011), dominant Brotherhood 2012 constitutional assembly members integrated certain Islamicaly inspired theological language in their 2012 draft that was not part of any constitution in Egypt's history, a draft that was later approved by MB Egyptian president at the time, Mohamed Morsi. This may have hinted to the other master narratives that the group intended on embedding a form of collective practice that would affirm Egypt's Islamic identity through supplementary regulations that are confirmative with Sharia. The same reference for an Islamic Egyptian identity was carried forward by Brotherhood supporters during Morsi's ouster in 2013 as they cheered, "Morsi is our 
President!" and "Egypt is Islamic" (Behn, 2013). With that, we can safely assume that the MB's aspiration for statehood is Islamic in principle.

For the secular master-narrative, the approval of Article II in the 2011 provisional constitution by the chair of the SCAF-appointed provisional constitutional committee raised debates. Seculars' support for an amendment of the article was summarized in the "Post-Mubarak Era Public Debates" report. Michael Mounir, president of the U.S. Copts Association, alleged that the article was prejudiced, while Coptic executive Naguib Sawiris condemned Article II for "institutionalizing sectarianism” ("Post-Mubarak Era Public Debates," n.d., para. 4). In addition, Ahmed Sobhy Mansour, the leading capitalist figure who promotes a secular state for Egypt, pushed for an amendment of the article, reaping severe reproaches from mainstream Salafists and Muslim Brotherhood scholars (“Post-Mubarak Era Public Debates," n.d.).

Years before the 2011 revolution, Coptic Pope Shenouda III of the Coptic Orthodox Church of Alexandria dismissed the official representative of the church, Anba Morqos, for having suggested the abolition of Article II, and advised Copts not to demand its removal. Again, in March of 2011, Pope Shenouda reiterated his position to avoid sectarian tension:

I believe that at the current stage, it is difficult to oppose this article, especially for Christians. As a compromise, I suggest the following, if it is essential to keep it, we may add a sentence "as for non-Muslims, the commandments of their religion shall apply in personal statute and clergy matters." ("Post-Mubarak Era Public Debates," n.d., para. 2)

Morqos's suggestion to abolish Article II reflects the Coptic's displeasure with Egypt's Islamic identity and their fear of Egypt's Islamization, while Shenouda's compromising suggestion reflects the varying approaches amid the Coptic sub-narrative. The above 
communications highlight the focal aspiration for both the Coptic Christians and

Capitalists, which is a clear separation between church and state, without necessarily limiting the military's power in manifesting this goal.

As for the military's view on statehood, it was no secret that they prioritized national security through a pan-Arabism ideology since the revolt of 1952 . Yet, they also sided with the protestors and remained uninvolved up until they backed military candidate Ahmed Shafiq in the 2012 presidential elections. Salem (2013) explains the military's initial position, saying:

It appears that the revolutionary protests succeeded in toppling Mubarak because the military decided to "side with the revolution." This was not necessarily out of sympathy for the demands of the protesters, however, but because the military made a strategic calculation. (para. 18)

Later in the discourse, we gain further understandings of the military's position in 2013 during Morsi's ouster. Excerpts from Al-Sisi’s speech at the graduation ceremony for the Navy and Air Defense Academies exposes the military's national concerns:

I said Egyptian national security is at risk amid internal political differences, to which some were surprised..., I ask all honorable and faithful Egyptians to take to the streets on Friday, to mandate me to confront terrorism and violence. I did not ask of you anything before. I want you Egyptians to delegate the army and the police to confront violence in a suitable way. Please bear the responsibility with the army and the police. Show your steadfastness. This does not mean that I want violence or terrorism. (Mesalhy, 2013)

Here Al-Sisi uses a combination of topoi (Plural of topos) (Wodak \& Boukala, 2015), the topos of threat and the topos of national responsibility, which states that when national security is at risk one is obligated to respond. He uses both topoi in order to mobilize action towards what he branded in his communication, using referential 
discursive strategies and the topos of definition (which hints that by definition certain things are treated in certain manners), as terrorism.

Al-Sisi also said, "He is wrong whoever believes that we will be silent against any upcoming harm, and I hope they realize and we all realize the danger of that on national security” (Mesalhy, 2013). He also clarified saying:

The army's decision to intervene [on July 32013 ] was dictated by national interest, national security necessities, and fears of a civil war breaking out...if the situation continued.... We believed that if we reached civil war, then the army would not be able to stop it. (Al-Youm, 2013b; Mesalhy, 2013) ${ }^{3}$

Here al-Sisi focuses on national security as the central motivator for necessary involvement. He uses the topos of threat to warn that the possibility of civil war poses a threat to national security, thus creating a situation that requires the intervention of the armed forces. He also employs the topos of definition by equating Morsi's regime with terrorism; this aids in the creation of a worldwide-understood threat that requires local and international support. His communication as a whole also employs the topos of burden, which argues that if a person, an institution, or a country is burdened by specific problems, one should act in order to diminish those burdens" (Wodak \& Boukala, 2015, p.97).

During his army resignation speech, when he announced his run for presidency, Al-Sisi continued to refer to state security and national defense as current priorities, saying:

Great people of Egypt Today, I stand before you in my military uniform for the last time after I have decided to end my service as the Minister of Defense....I have spent my entire life as a soldier in the service of the nation and in the service of its hopes and aspirations and I will continue to do so God willing. And I will

\footnotetext{
${ }^{3}$ For a similar statement about the risk of unstoppable civil war, see his remarks on August 18, 2013, at http://www.youtube.com/watch?v=LC93fn9s3-c.
} 
always be proud of wearing the uniform in defense of the nation and today I leave this uniform in order to defend the nation. Therefore, I am here before you humbly stating my intention to run for the presidency of the Arab Republic of Egypt....Only your support will grant me this great honor. I appear before you to speak from the heart...to say to you that I am representing the appeals a wide spectrum of the Egyptian people demanding that I run for this honorable office. (Egyptsource, 2014)

Al-Sisi again uses the topos of national responsibility to explain the necessity for his resignation from the army with the presidential campaign statement "I leave this uniform in order to defend the nation." He further uses the topos of national responsibility when he claims that the majority of the Egyptian people are "demanding" that he run for office, and thus, because of national responsibility, he must do so. This also shows his attempt to normalize the collective mainstream view as one in need of a national security protector.

This concludes that the aspirations for statehood on the democratic masternarrative's side were largely democratic, with a parliamentary system that limits the military's power and religious influences. It also shows that the Islamic master-narratives aspirations were largely Islamic in nature, yet for various reasons. For the Brotherhood, it related to insuring the establishment of an Islamic state, for the Salafists, it related to the protection of Islam as a practice in Egyptian society through an Islamic national Identity, and for the Sufis, it related to national stability and order. Finally, the above sheds light on the secular-master narrative militant and secular version of statehood, with a strong separation between religion and state agenda, and an over powered military to insure its application. 


\section{Polarization: In-Groups and Out-Groups}

From the above, it is clear that Mubarak's removal charted an opportunity to redefine the Egyptian state. The nationalistic degrees of each master-narrative, and subnarrative or individual within that master-narrative, determined how inclusive or exclusive they were in their definition. Hardcore nationalists, who view their group as majestic, became far more exclusive and regarded the diversity as problematic (Kriesberg, 2003; Anastasiou, 2008). This exclusive attribution of a single ideology to the state, fueled by the nationalistic view of homogeny, was especially problematic within the ideologically diverse Egypt. This is because it causes identity groups outside of the ideological definition to become the outcast (Anastasiou, 2008; Dingley, 2011), and as such, in the case of Egypt, it triggered intergroup conflict amid the three masternarratives that heightened during the referendum of 2012.

On the Islamist side, the Brotherhood portrayed the approval of the 2012 constitution as a majority consensus. Their celebratory comments ignored the opposing views and allegations from democrats and seculars, along with the low turnout of eligible voters (Linton, 2012). Their rhetoric only aimed to normalize the approval as desired by most of the Egyptian population. Sensing the tensions, Morsi, after signing the constitution into law, attempted to win over the opposing democrats and seculars saying:

We don't want to return to an era of one opinion, fakeness, and manufactured majorities. The maturity and consciousness [of voters] heralds that Egypt has set on a path of democracy with no return.... Regardless of the results, for the sake of building the nation, efforts must unite. There is no alternative to a dialogue that is now a necessity. (Beaumont, 2012, paras. 8-9)

In this message, Morsi uses the topos of definition to define the previous regime as single opinioned, fake, and a manufacturer of an unrealistic majority. Then, he 
juxtaposes that undesirable definition against the desirable "path of democracy," which, in his view, his presidency has accomplished. FJP's media advisor commented on the majority "yes" vote for the 2012 referendum, saying, "We hope approving the new constitution would be a historic opportunity to reunite national forces, on the basis of mutual respect and sincere dialogue, in order to achieve stability in this homeland and to complete its constitutional institutions" (Hussein, 2012, para. 3). Acting as minister of defense and also sensing the tensions, Al-Sisi then said, "Anything other than that [dialogue] will force us into a dark tunnel with disastrous consequences" (Associated Press, 2012a).

Yet, the divides where eminent, as one activist said:

The divides and polarization are here to stay...The sectarian rhetoric of the "yes" campaign...by Brotherhood leaders will have long-lasting ramifications... The passage of the constitution is unlikely to usher in any semblance of stability, and in fact might institutionalize the current political crisis. (Hussein, 2012, para. 18)

Another liberal figure said, "I see more unrest...People are not going to accept the way he [Morsi] is dealing with the situation" (Hussein, 2012, para. 19). Hamzawy said that democrats would use "all peaceful, democratic means to challenge the constitution" (Hussein, 2012, para. 14). Consequentially, rigidity became the first step in deepening the polarization. In response to Morsi's request to dialogue and call for parliamentary elections in 2013, the NRF was reported by Aljazeera news saying the following, "The decision of the front, unanimously, is to boycott the elections... We tell President Morsi: talk with yourself and your party." (paras. $2 \& 10$ ). On that note, Marina Ottaway, a Middle East Fellow at the Woodrow Wilson Center and a longtime analyst of political transformations in the Middle East, captured a sound prediction saying: 
It's very paradoxical for an opposition that claims to defend democracy to be rejecting elections at this point and the decree issued last November by Morsi was certainly not democratic.... Neither party is acting democratic, so it seems that they are moving toward a very heavy confrontation. (McTighe, 2013)

Yet, the polarization seed had been planted since the courts dissolved the Islamicaly dominant lower house of parliament in 2012, to which Morsi responded saying that some groups in Egypt plan "ill against the people" (Hearst \& Hussein, 2012, para. 10). Here Morsi uses the topos of threat to create a situation of conspiracy to foster unity by implying that some groups (out-group) plan ill against the people (in-group). In that sense, Morsi's absolutist power decree could easily be viewed as a response to the courts' verdict, a "tit for tat" conflict strategy, since the Brotherhood feared that the courts would rule similarly against the Islamicaly dominant upper house and constitutional assembly. Nevertheless, the fact that the Brotherhood raced for all facets of government after the Mubarak ousting contradicted their initial position, placed the democratic and secular narratives, along with the courts, on the defense, because they feared the Islamists would "hijack" the revolution.

Arguably, the predisposed suspicion on all ends may have been what set the tit for tat dynamic in motion to begin with. For example, The Brotherhood's fears heightened after witnessing the democratic and secular narratives' reactions to their dominance in parliament and the constitutional assembly. Hamzawy for instance relayed the following before Morsi announcing his decree of full power and the 2012 referendum:

Questions about the legality and constitutionality of the second Constituent Assembly cloud its future.... The constitutionality of the Constituent Assembly is currently under review by the Supreme Constitutional Court, which is expected to make a decision by December 12 [2012]. This will likely mean the Constituent Assembly will be disbanded unless President Morsi intervenes.... The Constituent Assembly is dominated by Islamists and has marginalized many key groups and 
stakeholders in Egyptian society, including women, minorities, and members of the labor movement among other groups....Also, some liberal figures have threatened to pull out of the Constituent Assembly; this contentious environment is not conducive to drafting a constitution....Furthermore, many assembly members lack legal and constitutional expertise, resulting in several contradictions and mistakes in the draft constitution. (Hamzawy \& Fakir, 2012)

In this message, Hamzawy objects to the Islamic dominance in the assembly, attributing it covertly to diversity issues and the illegality of parliamentary elections rather than potential religious constitutional language imposed by the Islamic dominance. Hence, he uses Wodak and Boukala's (2015) predicational strategies to attribute negative characteristics to the many members of the assembly, such as their "lack of legal and constitutional expertise" (Hamzawy \& Fakir, 2012). These comments conflict with his democratic viewpoint, as advocates of democratic systems accept democratically elected assemblies, regardless of their composition. The comments are clearly hints to the Islamist dominance, which in turn cause an apprehension on the MB side.

Ottaway (2012) commented on the true root of this anxiety saying:

They [seculars, liberals, and activists] are demanding that the Constituent Assembly be composed primarily of representatives of organizations outside the parliament — such as religious institutions [Al-Azhar], universities, and professional syndicates - which in their view represent the Egyptian people better than the elected parliament. Allowing the parliament to elect the Constituent Assembly as it sees fit, many argue, would allow Islamists to dominate the writing of the constitution. (para. 2)

The distress with the Islamists dominance was ever more evident in Hamzawy's speech after the draft was completed:

Criticism facing the constitutional project relating to personal, civic political freedoms and others. Concerning these rights and freedoms there are loose wording used in the first section: the state and the community section, and are used as well in the second section: the rights and freedoms and public duties section...wording that refers to "ethical fundamentals," \"inherent [social] customs," "inherent character" and the "ethical duties towards the state and the 
community"... The article 81 discusses my personal freedoms as a citizen, and each citizen's personal freedom...that each citizen exercises those rights within the scope of the fundamentals mentioned in the state and community section, what is mentioned in the state and community section? Loose wording that can be used to restrict my rights by a series of laws that might open doors wide for Egypt to restrict rights and freedoms [allowing] the state to intervene in our personal lives and our personal freedoms even in our community, which is undefined in this constitution. This opens the door for groups we would rather not have in Egypt; ones that we can metaphorically refer to as "the promotion of virtue and prohibiting of vice groups. " (DrAmrHamzawyOfficial, 2012; translated from Arabic)

In this communication, Hamzawy employs the topos of threat by suggesting the metaphorical consequence of a presumed danger from the presence of the promotion of virtue and prohibiting of vice groups (PVPV) in Egypt if Morsi's constitutional draft was approved. His opposition toward such groups is highlighted when he says "groups that we would rather not have," which creates assumptions that, one, these groups are unwelcomed and, two, all Egyptians would rather not have them, or ought not to want them. Thus, using the topos of threat, he blames the formulation of such groups on the constitutional draft to mobilize a "no" vote during the constitutional referendum. This discursive strategy created a sense of in-group, individuals who reject the PVPV, and an out-group, individuals who supported the PVPV.

Liberal Mona Makram-Ebeid also communicated a parallel sentiment, saying, "Women, Christians, intellectuals, all these were sidelined in the new constitution. They would say, 'you can have liberty of expression, freedom, etc.- - if it is in conformity with Sharia"” (Childress, 2013, "Nov. 29: Islamists Finish Draft Constitution”). During Morsi's ousting in 2013, one revolutionary said, "He is a president for the Brotherhood...He didn't respect the judiciary, the people or the constitution...He wants

\footnotetext{
${ }^{4}$ For Arabic translated script see https://www.youtube.com/watch?v=V7XsoqJiOGQ\#t=146
} 
to turn the country into a Brotherhood nation" (Abdellatif, 2013, paras. 13-14). The

discursive formation of the out-group is drawn upon by use of topoi that affirm negative attributions, and warnings, that placed the Brotherhood on the defense. This rhetoric schooled accusation and unrelated blame on the grassroots levels of all the masternarratives. For example, during the water crisis triggered by the Ethiopian dam construction project, a local shopkeeper said, "They [the Brotherhood] wanted an Islamic caliphate. They didn't care about Egypt as a country, so they did nothing to stop this [Ethiopian] dam" (Orsam Water Research Programme, 2013, p. 22).

On the secular side, military supporter journalist Mustafa Bakri criticized Morsi’s constitution and his declaration to retain the power to legislate and not transmitted it to the Shura council or any other branch of government saying:

This is an assault on the Constitution, which the president swore to protect...we are facing a President of the individual, judging without supervision and without a constitution and can issue any laws that uphold the rule of his group and his party, and that tax his opponents...it is enough that he granted himself the right to form a Constituent Assembly if the verdict of the judiciary is invalidates it, which means the issuing of a Constitution against everyone's will. Was this what the revolution was for? We have returned to sole ruling quickly and fiercely and with disregard for the Constitution and laws. ("Bakri: Morsi governs without censorship or constitution," 2012. translated from Arabic ${ }^{5}$ )

Bakri uses topos of definition to define Morsi's regime as dictating ("President of the individual, judging without supervision"). The discursive strategy employed aids in the creation of an out-group ("his group and his party") and an in-group ("his opponents"), also indicating competition on constitutional matters. He uses the Aristotelian fallacious

\footnotetext{
إن ذلك يعد اعتداء علي الدستور الذي أقسم الرئيس علي حمايته ويقضي علي مبدأ الفصل بين السلطات وقال: “لقد أصبحنا أمام رئيس 5 ألئ

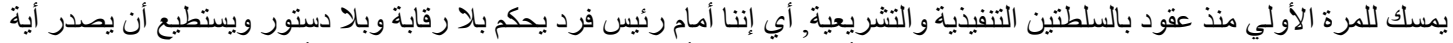

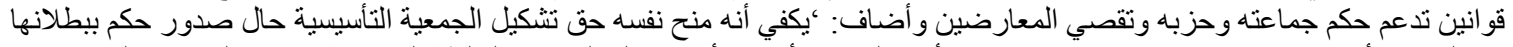

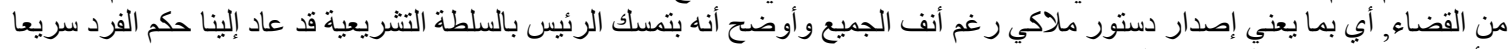

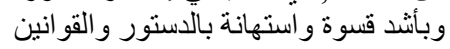


topos of aftermath to suggest that Morsi's decree that granted him near absolute power will result in him forcing a constitution. Bakri's comments aim to brand Morsi as a natural dictator, they fail to consider that the decree was a reaction on the Brotherhood's side when they feared the disbandment of the upper house of parliament by the courts; as with the lower house. His comments also fall short from envisioning future possibilities for negotiations and amendments; possibilities that can be built on hopeful scenarios similar to when Morsi agreed to withdraw his exclusive power granting decree before the referendum.

Secular figure Ahmed Mansour (2013) added to the constitutional criticism, allegations, and polarization, saying:

Endowments on monasteries and other properties was an Egyptian phenomenon when the Arabs conquered Egypt....It is natural in a governance system that is dominated by intolerance, injustice, and that uses religion as means of tyranny and slavery for Copts to be treated with injustice. An example is permitting endowments on Copts. We are not rooting in the field of research in this subject so as not to stray away from the basis of the topic [Morsi's constitution], but we suffice with revealing examples that point to the Brotherhood... and Salafist's current mentalities... The benefit from the foregoing is that the law in the Sunni fanaticism can be easily applied by perjury.... This happened in the... "Salaf" era [era of the predecessor of prophet Mohamed]. What prevents it being applied in the era of Salafists?? From here we understand the presence of the endowment article in the Constitution of Morsi. This article stands on the lookout for Copts. (translated from Arabic ${ }^{6}$ )

In this communication, Mansour draws a distinction between Arabs and Egyptians and uses topos of definition to define Arab Egypt as intolerant and unjust. This

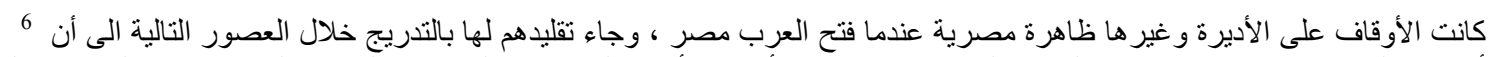

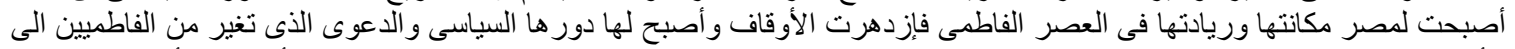

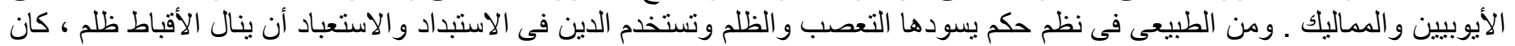

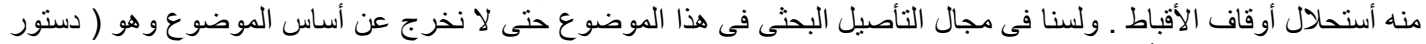

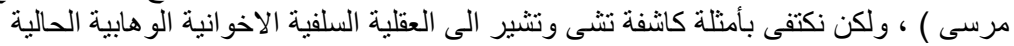


communication perhaps provides a clearer picture of the underlying reasons for the competition on governing systems. Mansour clearly criticizes the Arab's ruling system when he says, "It is natural in a governance system that is dominated by intolerance...that uses religion as means of tyranny and slavery...for Copts to be treated with injustice." He then makes the connection between Arabs' governing methods and the Brotherhood and Salafists' mentalities, circuitously tagging them also as intolerant and unjust. He uses the topos of threat when saying, "What prevents it being applied in the era of Salafists??" adding, "This article stands on the lookout for Copts."

In return, the Brotherhood also embraced rigidity when their position was threatened. For example, in June 2013 when the military issued statements implying that it would mobilize an intervention. Morsi's presidency released the following statement:

The president of the republic was not consulted about the statement issued by the armed forces.... The presidency confirms that it is going forward on its previously plotted path to promote comprehensive national reconciliation....regardless of any statements that deepen divisions between citizens. (Fayed \& Taylor, 2013)

When Al-Sisi was meeting with a number of religious, national, political, and youth icons and announced that there would be a statement issued regarding the intervention, the FJP replied, "We do not go to invitations (meetings) with anyone. We have a president and that is it" (Weaver \& McCarthy, 2013).

Days before the ousting, Morsi addressed the nation in a speech, saying:

Egypt has been invaded many times throughout history, and its enemies came between its people and its potential to be the state with the true message... That is evident throughout imperialist history, and the several revolutions came after that, with the last one, also the greatest one, the revolution of the 25th of January 2011. When we all stood in all the squares to say to the criminal tyrant that he must leave. (Mackell, 2013) 
Here Morsi uses the topos of definition to define historic imperial invasions as the enemy of Egypt, and further defines Mubarak as a "criminal tyrant." There is a discursive construction of an in-group when he notes those who stood in all the squares and that of an out-group when he references imperialist as enemies and tyrants as criminals - the construction of eligible and ineligible national identities.

He then adds:

But as you know, there remained tails, claws, the vandals and many challenges remained.... I see now, oh Egyptians, that this revolution is being stolen from us, and that it is desired for us to be submerged in a sea of never ending conflicts....I put a direct order, to all the forces, in the institutions, interior security forces, and the armed forces, that their role is the keeping of the security of the nation...that they also protect the legitimacy, that we all earned as a result of the presidential elections and before that the parliamentary elections and after that the constitutional referendum. So those, who are the sons of this nation, are asked to protect the legitimacy and to protect this nation, and that constitutional legitimacy and legal legitimacy, and that the voice of the people, of this people that have erected this legitimacy, would be the reason to protect this nation. (Mackell, 2013)

In this case, Morsi uses the topos of threat to elucidate that there is remanence of the previous regime by saying "there remained tails, claws, the vandals," then using the conceptual metaphor "being submerged in a sea of never ending conflicts" as a means of explaining the grave danger from such a threat. The threat is also used to mobilize action and is further stretched using the topos of national responsibility, when he says, "I put a direct order, to all the forces...that their role is the keeping of the security of the nation" and "those, who are the sons of this nation, are asked to protect the legitimacy." He then orders the people, saying:

We must protect the constitution... on which was conducted a referendum, and which was approved by $64 \%$ of Egyptians, and have settled on its content of articles, and which has been settled on by the Egyptian judiciary....And now, it is demanded that this constitution be suspended, I absolutely refuse that, and call on 
you to protect it and to hold on to it, and to not accept any alternative to it. (Mackell, 2013)

Here Morsi uses a fallacious logic to establish the constitutional legitimacy as universally accepted by the majority of Egyptians, even though 30\% of Egypt's eligible voters approved it.

Morsi again used the same topos of threat and the furthering construction of inand out-groups on June 26, 2013, when he said:

It is no secret to any rational being that there are some abroad who are overtly hostile to this revolution. There are those who realize what a free, strong...developed Egypt could provide to its community, both at home and abroad...those who crave the ability to turn back the clock and revert to the state of corruption, oppression, monopolization and injustice. It seems, unfortunately, that there are those among us who cannot imagine being able to eat or live without it. Egypt's enemies have spared no effort in attempting to sabotage the democratic experiment. They have led it into a state of violence, defamation, incitement, and corrupt financing, as well as playing with fire in vitally important institutions. It is known that the remnants of those who benefited from the old regime have difficulty in seeing Egypt rise up. There is a national opposition, and we cannot do anything but stand side by side in order for to become stronger and have a popular presence whereby it carries out its basic roles in the alternation of power, democratic oversight, and presenting alternatives for ruling and development. (Atlantic Council, 2013)

In this communication, the construction of out-groups is embodied by "enemies of the revolution" and "the democratic experiment," enemies who "benefit from the old regime." The in-group then is being called upon to unify and "stand side by side," which is the responsible action under such threatening conditions, argued for by the topos of threat, the topos of national responsibility, and the topos of burden. Morsi uses "playing with fire" as a metaphorical attribution to the actions of the corrupted old regime and its remains (the out-group) in order to heighten the severity of those actions and the dangers of them enduring. 
As Kriesberg (2003) states, inter-group conflicts occur when each side believes the battle is between 'us' and 'them"' (p. 2), and as such, the three master-narratives antagonistically separated themselves from each other. Yet, the positive interdependence between the goals of some master-narratives, and between some sub-narratives, resulted in some temporary alliances. Some examples were the short unity between the military and the Islamists regarding their views on article II of the constitution in 2011, the united outrage between democrats and Islamists when Ahmed Shafiq entered the presidential elections in 2012, and the formation of the NRF against the Brotherhood. The tit-for-tat strategy embodied by the courts disbandment of the lower house, followed by Morsi's exclusive power decree, and the formation of the NRF, shows that either side could stimulate its opponent to act competitively or cooperatively depending on how they behave when it is their turn to act. Yet, the zero-sum mentality of the nationalistic mindset is what constituted a competitive approach for each party to reach its goals, and in Egypt's case that has shown to have distressing consequences.

\section{Threats and Violence Justification}

As polarization shuts down communication and takes the conflict towards "autistic hostility" (Coleman \& Deutsch, 2015, p. 42), the deepened division breeds justified violence. In May 2013, one month before thousands advocated for Morsi's ousting, Al-Sisi warned, "No one should think that the solution is with the army...This army is a fire. Do not play against it and do not play with it" (Sabry, 2013, para. 7). AlSisi uses a conceptual metaphor to describe the army as a dangerous fire in order to instill fear in those attempting to challenge it. On a television broadcast, Al-Sisi also said, "Whoever causes harm to the Egyptian army is causing harm to the Egyptian people" 
(Hussien, 2013), thus using the topos of definition to define harm to the army as harm to the nation, which connects the actions to national treachery, fueled by the nationalist mentality.

On the same accord, during Morsi's ousting, a Muslim Brotherhood parliament member perpetuated the situation and warned Christian communities saying, "Do not sacrifice your children...general Muslim opinion will not be silent about the ousting of the president" (Morgan, 2016, p. 504). This draws a completely demonized imaged of others through a de-personalizing discursive strategy (Wodak \& Boukala, 2015) that deprives Christians from the right to life, and thus justifies violence for the sake of nationalistic causes. Days before the ousting, Morsi himself intimidatingly said, "When there's violence and thuggery I must act," (Ghattas, 2013, paras. 10). He then added in a televised speech:

keep [protect] Egypt, keep [protect] the revolution of January $25^{\text {th }} \ldots$ keep protecting the revolution which we have gained with our sweat and the blood of our martyrs...don't let the revolution be stolen from you, with any excuse, and there are many excuses, and there are many magicians, and the challenge is huge... if the price of defending my legitimacy as elected is my blood then I am ready...there is no substitute for legitimacy. (Islam Elmasry, 2013).

Here Morsi uses topos of threat, the threat of losing Egypt and the revolution, along with the metaphorical use of sweat and blood of martyrs, to instill a sense of need for swift action to counter the danger that will ultimately waste an enormous effort. Then he uses the topos of national responsibility, which is also in essence a religious nationalistic mantra, dying for the sake of national protection and sovereignty from, , magicians (another metaphorical representation) i.e. tricksters, who only want to trick the people of Egypt and steal their pronounced accomplishment of justice and legitimacy. 
Closer to the time of the ousting, and in response to Morsi's comments, SCAF

released its ultimatum in June of 2013:

The Supreme Commander in Chief of the Egyptian Armed Forces had mentioned before that it's better for us to die rather than seeing the Egyptian People being threatened or horrified, and we swear that we would sacrifice our lives and our blood for Egypt against every terrorist or extremist or ignorant. Long live Egypt. (Egyptian.Armed.Forces.Admins, 2013)

Here SCAF uses a combination of topoi-the topos of definition and the topos of threat - branding the Brotherhood as "terrorist or extremist or ignorant," while framing his communication within the standardized nationalist mantra, sacrifice in the name of the nation.

On the democratic side, only a handful of democrats were in opposition of violent intervention, while most democratic master-narrative figures justified violent intervention using other fallacious topos. Writer Alaa al-Aswany for example commented after the Brotherhood ousting, saying:

I cannot defend killing....But in the end, there is a very big difference between when you use excessive force during a war and when you use excessive force during an ordinary, peaceful situation....We are in a state of war....[Morsi's Muslim Brothers] are not the peaceful, democratic force that they said they were for 40 years.... They are a group of terrorists and fascists... You had Mubarak, who was terrible. But now you have been scratched by the Ikhwan [the Arabic name for the Brotherhood] and what do you prefer? The return of the old regime, or staying with the Ikhwan?...We don't want the Ikhwan, and we don't want the old regime. We want a democratic state. (Kingsley, 2013)

In this scenario, Aswany uses a fallacious topos of reality, which argues that "because reality is as it is, a specific action/decision should be performed/made" (Wodak \& Boukala, 2015, p.97), followed by the topos of burden, to establish validity and need to the use of excessive force against Muslim Brotherhood supporters. That is, since MB protestors exhibited the use excessive force, the nation is therefore in a state of war, and 
because the nation is in a state of war, the military must act accordingly to moderate this burden of war. The argument is also expanded on using the topos of threat, evident in "war", and the topos of definition, evident in labeling the MB "a group of terrorists and fascists." He then creatively relays his views on statehood by mentioning the other two narratives, the secular narrative (the old regime) and the Islamic narrative (the Ikhwan; The Brotherhood in Arabic), and argues that the third narrative (democratic state) is what "we" (Egyptians, collective society) desire.

Similarly, young revolutionaries celebrated the military's action to oust Morsi. The Tamarod (see profiles) movement's leader said, "This is a president threatening his own people. We don't consider him the president of Egypt" ("Egypt's Mohammed Morsi Defiant," 2013, “Threatening His People," para. 6). This discursive strategy attributes illegitimate qualities to other groups and individuals as a means to demonstrate electoral unworthiness and disrespect for an elected president. A young artist, for example, said, Morsi has lost all legitimacy in the eyes of the people, especially after yesterday's speech. As a leader, he is responsible for those who died...He didn't even acknowledge that those who died were revolutionaries. He spoke 24 hours after the violence. This is not a president for Egyptians. (Abdellatif, 2013, paras. 1112)

Denying the Brotherhood of Egyptian identity worthiness, a young activist backing Morsi's removal said that the Brotherhood were "un-Egyptian" and "displayed dual loyalties." (Dunne, 2013, paras. 5). He then confirms the conflict's underlying motive, the Egyptian national identity debate, by saying, "Even if in the end the military betrays...we will still be better off than if the Brotherhood had stayed in power; at least we will preserve our national identity.” (paras. 5).

Moreover, Egyptian liberal politician ElBaradei also stated: 
Let me make one thing clear: This was not a coup. More than 20 million people took to the streets because the situation was no longer acceptable. Without Morsi's removal from office, we would have been headed toward a fascist state, or there would have been a civil war. It was a painful decision. It was outside the legal framework, but we had no other choice. (Sultan, 2013, para. 2)

Here ElBaradei uses the salient topos of threat to create the fallacious danger, which is based on the condition that Morsi's continuation guarantees the emergence of a fascist state. This argument is furthered by the employment of the Aristotelian fallacious topos of the aftermath, based on the condition that if Morsi stays, then there would be a civil war. He then admits it was a decision "outside the legal framework" but argues that there was "no other choice," and therefore it was justified (Wodak \& Boukala, 2015).

Meanwhile, Brotherhood supporter author Magdi Moghera (2015) mourned the loss of Morsi's supporters in the Rabaa sit-ins (See major events between 2011-2014) saying:

In Rabaa, and in the Renaissance met the elite of the people of Egypt, they met to become truly victorious, and regain their voice that they placed at the ballot box, and declare the word of truth in front of a rapist that thought that tanks and cannons will frighten them and mute their tongues.... These pure people are the ones who were shot by the coup using anti-aircraft bullets fearing Kalashnikov bullets would not kill them.... These pure people are whom the bulldozers of the coup would lift their shroud wrapped bodies to place them in garbage bins so they can go out in the desert and burry it as buried waste, without regard to humanity, nor regard for the values, nor the shaking of conscience. They have done what they have done, they did not know that the massacre will be a curse on them in this world before the Hereafter. (translated from Arabic ${ }^{7}$ )

Moghera uses the topos of definition to define al-Sisi as a "rapist" and designates the military operation as a "coup" that has killed "pure people," thereby crystalizing the

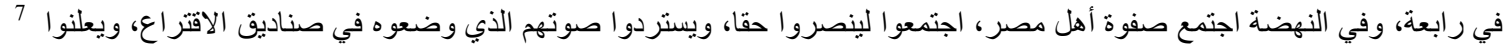

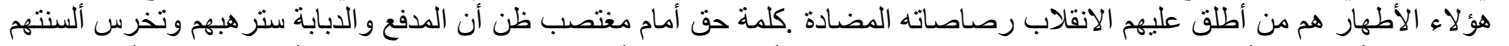

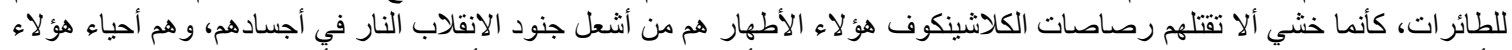

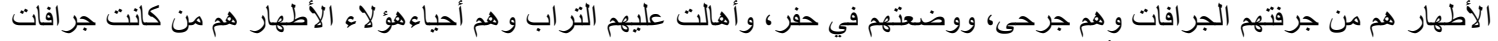

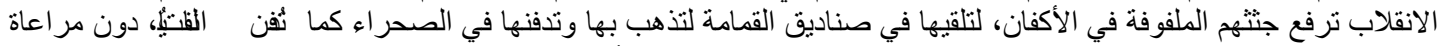

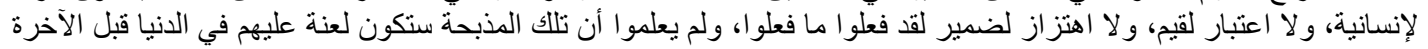


image of two distinct opposing groups, a demonic and a pure group. He then attributes through religious denominations that the actions warrant a divine "curse," which highlights the leading religious nationalist outlook embraced by the Brotherhood and its supporters. Similarly, after the ousting, a militant Islamic group announced after carrying out a successful suicide bombing operation, "God allowed us to break the security system of the Minister of Interior...through a suicide operation committed by one of Egypt's lions that made the Interior butcher see death with his eyes, and what is to come will be worse" (Saleh, 2013).

Later after the ousting, Al-Sisi said:

The economic, social, political and security realities [in Egypt] — whether before January 25th Revolution 2011 or the accumulations afterwards until June 30th Revolution 2013... have reached the limit that requires an honest and brave confrontation of challenges. This is not acceptable either. [Egyptians deserve a better life than this.] They deserve to a lead a life of dignity, security and freedom.... [The wheel of] production has to resume in all sectors, [with all of its power], to save our country from real dangers [it is passing through].

(Egyptsource, 2014)

Here, Al-Sisi use the topos of definition to define Morsi's ousting as another "revolution," versus the Brotherhood's perspective of it being a "coup," by paralleling it to the revolution of 2011 against Mubarak, hence also describing it as a revolution against tyranny. He does so in order to normalize the ousting as one of pronounced historical accomplishment. Additionally, due to his nationalistic predisposition, he frames national "security" as a collective Egyptian need, and as one of the necessities to save “our country" (in-group) from "real dangers" (out-group), in reference to Morsi's regime.

He also added:

The State needs to regain its...prestige that was injured during this past period. What [we have] witnessed in recent years, [whether] in politics or the media, 
internally or externally has caused the nation at times to be violated. It is time for this disrespect and intrusion to stop. This is a dignified and respected country, and everyone needs to know that this is a decisive moment, that disrespecting Egypt's right is a gamble which comes with consequences [and reckoning]. Egypt is not a playground for any internal, regional or international party and it never will be. The abilities and talents possessed by the Egyptian people for seven thousand years have to ally with hard work. It is the hard, sincere, and patriotic work that creates successful countries [advanced countries]. (Egyptsource, 2014)

Al-Sisi here aims to use the "the triadic structure of nationalist rhetoric" (Levinger \& Lytle, 2001), which is a nationalist process of mobilization that connects the glorious past and degraded present and the hope for a utopian future. Here, the degraded present ("recent years," or the Brotherhood's era) is presented in the form of injured national pride and "disrespect" toward Egypt. The glorious past extends back to the Pharaohs' dynasties ("abilities and talents possessed by the Egyptian people for seven thousand years"). Al-Sisi goes on, using topos of threat, to remind the people why he must run for president and describes the utopian future saying:

We are threatened by terrorists... by parties who seek the destruction of our life, safety and security. It is true this is my last day in uniform but I will fight every day for [an] Egypt free of fear and terror.... I repeat what I have said before: "We'd rather die before Egyptians are terrorized." Allow me to speak about hope...hope that is the outcome of hard work...hope that is the security and stability. Hope is the dream to usher Egypt to its leading place in the world. It is the dream to restore its strength, power and influence and teach the world as it did before. I cannot make miracles. Rather, I propose hard work, and self-denial with no limits. If I am granted the honor of the leadership, I promise that we together, leadership and people, can achieve stability, safety and hope for Egypt...God bless Egypt and its glorious people. Thank you. (Egyptsource, 2014)

Later, after he won the presidency in 2014 , he continued to normalize the ousting within the Egyptian historical narrative saying that Egyptians made history in the past two years by revolting against corruption and despotism to claim their right to freedom, dignity, and social justice. He applauded the Egyptian people for refusing to yield to the 
tyranny of a faction that in the name of religion had put its narrow interests before those of the people and strove to undermine the democratic process ("Egypt," n.d.).

As demonstrated, the analysis demonstrates how fossilized creations of in-groups and out-groups formed demonized enemy images on all sides of the three masternarratives to a point where truth of who is to blame became vague and frivolous. Each group equally claimed the liability on the other groups for placing Egypt on the path of ruin. This demonization licensed an atmosphere in which mass killings became justified, adding a complex layer to a conflict originally about drafting a constitution. Ashraf Khalil captures this toxic atmosphere during the 2013 ousting saying:

The animosity against the Brotherhood is so intense that there really does seem to be a desire to just wipe them off the political playing field. And I've had conversations with people where their solution is, in Arabic translates to, "Just round them all up."... How do we function as a country when we've rounded up 15 percent of the dissidents? (Childress, 2013, paras. 32).

The violent exchanges deepened mistrust, as agony became the primary reference for facts (Anastasiou, 2007). As the conflict progressed particularly towards the Rabaa incident, and until present day, the sole experience the three competing narratives have of each other became the sum of hostile incidences. The deep meaning that this violence communicates replaces all messages by false assumptions (Anastasiou, 2007). Thus, AlSisi became one side's champion and the other side's scoundrel, and so did Morsi. Today, each master-narrative has but to mourn for the trials experienced by their ingroup.

\section{Discussion}

The analysis shows that the duration of the constitutional battle was a context in which the legitimacy of all political leadership, beginning with Mubarak and ending with 
Morsi, became vulnerable. Within this context, it is common for political leaders to employ national identity as a plea to inaugurate homogony, which explains the attempts of polarization and the creation of in-groups and out-groups amid the three masternarratives (Maiese \& Norlen, 2003). Yet, the analysis reveals that Egypt's national identity dilemma extends beyond a mere plea against chaos, reflected by the nationalistic arguments underscoring the constitutional battle. The varied aspirations represent the tip of a thread that leads to deeper reasons as to why there are multiple narratives in Egypt to begin with. This sheds light on correlations between a resolution for the issue of defining an Egyptian national identity and a resolution for the disagreements on constitutional matters. However, my second claim argues that the complexity of defining an accurate Egyptian national identity, due to its equivocal nature-produced by the long-gone narrative-makes it an unsound topic for absolute resolve.

As the historical narrative reveals, since the Pharaohs, Egypt has been ruled by outsiders up until the 1952 military revolt; thus, from a modern-day Egyptian viewpoint, Nasser's rule returned Egypt to its lawful proprietors. Still, in reality the bygone narrative has had its traumatic impact on collective identity loss, making it illogical to think that modern-day Egyptians are anything but a melting pot of genealogically and ideologically assorted and bewildered identity clusters (Bassett, 1994). This identity-loss progression charted a vacant space with prime conditions that offered a need for unifying novel identities — in particular, ones that called for a separation from conquerors - a truly distinctive Egyptian character; a counter nationalism as mentioned in the literate review of this thesis. 
Ironically, Egyptians' encounters with Greek, Roman, Arab, Napoleonic, and British models of sociological and militaristic governing systems were the points of reference for redesigning these counter nationalisms. Wynn (2007) builds on how national identities are constructed through mimicking others as a result of intercultural mixing saying:

The comparison of Arab and Western experiences in Egypt reveals how national identities are created partly through encounters with cultural others. This research links up the cross-cultural projects of tourism, archaeology, and cultural performance as components in the production of multiple, contested, and often competing imaginations of nation and people. (p. 21)

Even though Wynn's work focuses on modern-day encounters through tourism, if the concepts are applicable for these short-term interactions, then they are easily transferable to long-term encounters that took place during the empire-building eras. This confirms the idea that through Egypt's encounters with others, modern Egyptian national identities were defined. The process by which these distinctive identities were forged is crucial to the understanding of important intractability facets to the conflict, namely its continuity and the equivocal nature of single Egyptian national identity.

The idea of the nation-state presented a new trend of unifying identities; an awareness of national identity grew in Egypt during the late 19th century and early 20th century. To trace the evolution of this Egyptian national awareness, I referred to anthropologist Winifred Blackman's (2000) The Fellahin of Upper Egypt, a book that studied Egyptian farmers and was first published in 1968. I chose Blackman's book because his findings hypothesize that the fellahin (farmers) exhibited ancient Egyptian traits, shedding light on their existence during Pharaoh Egypt, and hence they represented one of the most popular theories for "original" Egyptian. Yet, as seen today, the fellahin 
have also amalgamated into some aspects of the civilizations that followed the Pharaohs, through religion, culture, and education. The religion aspect is evident in seeing Christian fellahin and Muslim fellahin, while the culture aspect is apparent by acquired dress codes, culinary recipes, and more. The fez or tarboush, for example, was adopted during Ottoman Egypt and was worn by leading figures of all three master-narratives whom are all of fellahin origins.

The influence of education on the other hand, traces back to the time of Muhammad Ali's Egypt, when some fellahin offspring had to choose between advanced schooling and joining the military. If they became literate, they had a chance at earning the title of effendi (a title of nobility used in the Ottoman Empire equal to the English sir) or becoming religious scholars. This process of migrating and educating the fellahin from rural to urban created their attentiveness to the idea of them being legatees of Egypt (Sayyid-Marsot, 1977). Muhammad Husayn Haykal's 1913 novel titled Zaynab (Brugman, 1984) describes the lives of fellahin and scorns urban intellectuals for stalling against British occupation. Haykal wrote, "British remain in the country and the khedive remains in power...only through unity can the literate classes effect change, just as the peasants cannot overcome tyranny until they stand up together" (Gasper, 2009, pp. 213214). Brugman (1984) says that Zaynab was first published under the name "Misri Fallah," meaning "Egyptian of peasant origins," hinting to an "autochthonous Egyptian." This shows how aware Haykal was of the idea that he was an Egyptian not belonging to the Turco-Circassian rulers.

This new national awareness was funded by Britain's assimilation for many Arab and Egyptian intelligentsias, which resulted in them housing the values of the French 
Revolution to the degrading conditions of the Muslim world. In this group was Jamal alDin al-Afghani, his student Muhammad Abduh, and Abduh's student Rashid Rida (Ginat, 1997, p. 101), who together raised questions about Islam's role in the modern world and provided central answers to the evolution of Egyptian nationalist thought (Cook, 2011). Prominent followers who strove to further these thoughts were Mustafa Kamil, Ahmad Lutfi al-Sayyid, Ahmad Fathi Zaghlul, and Saad Zaghlul (Ginat, 1997, p. 101). Lutfi alSayyid's writings (Ahmed, 1960, p. 95) and Ahmad Fathi Zaghlul's translations of Anglo-Saxon education stirred collective criticism against Egypt's rulers and charged independence (Ahmed, 1960, p. 46).

However, disagreements about Islam's role in this modern transformation initiated major divides among these rising political leaders. Richard Bulliet's (2002) The Crisis within Islam traces the roots of this dilemma of interpreting Islam in modernity back to when some rising Islamic nationalist embraced reforms based on European models that replaced Islamic Sharia law. This was because Abduh's disciples showed significant differences in interpreting his thoughts; Al-Sayyid, for example, was not as committed to the centrality of Islam as Abduh was. He objected to the British and Ottomans because they ruled absolutely, but decided that Islam and nationalism were incompatible, and thus, turned to liberalism (Cook, 2011, p. 17). On the contrary, Islamic scholars such as Hassan al-Banna viewed national identity as the modern vessel for Islamic religious identities, while rising militarized fellahin attuned themselves to secular nationalism. Consequentially, each of the three groups synthesized a modern national identity narrative utilizing their religious, cultural, and educational pathways, which are essentially projections onto qualities of specific eras of the Egyptian historical narrative. 
These three groups whom represent three pathways of constructing modern Egyptian national identities highlight how the 2011 conflict actors are merely spawned apprentices of Egypt's early 20th-century intellectual blooming.

To exemplify, the democratic master-narrative nested mainly in Pharaonic nationalism, or Pharaonism (Reid, 2015), which suggests an Egyptian national identity dating back to the Pharaohs, separating "Egyptian-ness" from the rest of the Islamic world. Later cohorts such as Saad Zaghlul, Ahmad Lutfi al-Sayyid, and Taha Hussein (all of fellahin origin) anchored Europeanism to the modern Egyptian self-image (Wynn, 2007). Taha Hussein, for instance, debated that Egyptian national identity cannot be premised solely on religious or linguistic grounds, because "the Egyptian mind has retained a distinctive character based in part on the legacy of ancient Egypt and in part on the inspirational impetus derived from Egypt's historical and organic rootedness in a Graeco-Roman world” (Suleiman, 1996, pp. 31-33). Furthermore, Hussein argued that non-Muslim Egyptians would be sidelined if Islam was the source of Egyptian national identity (Suleiman, 1996), paralleling the arguments made by liberals/leftists and young revolutionaries during the 2012 constitutional battle.

The democratic narrative was charged in 1906 after a quarrel amid Egyptian farmers and British soldiers resulted in the hanging of four farmers. The episode, known as the Dinshaway Incident, triggered the finding of the first liberal political party in Egypt, the Umma (the Nation) Party by Ahmad Lutfi al-Sayyid. Egypt's partial independence from Britain in 1920 and the discovery of Tutankhamen's tomb by Howard Carter in 1922 strengthened the Pharaonic element of Egyptian nationalism, and paved the way for Saad Zaghlul's rise as a political leader in 1924 (Wynn, 2007). Zaghlul was 
born in a rural village in the fellahin of Egypt and while attended Al-Azhar University he was amongst those fellahin that also studied at a French law school in Cairo and traveled to Europe. Yet his achievements were due to his affiliation with Egyptian rural idioms, as he reaped such immense admiration among the Egyptian people that he was branded "Father of the Egyptians" (Cleveland, 2004). His worldview was largely liberal rather than religious, and organized mass movements demanding an end to the British colony. When the British exiled him to Malta, the Egyptian people staged rallies, marking their first 20th-century revolution. Upon his demanded return, Zaghlul led a new movement through the liberal Wafd Party, drafted a new constitution in 1923 based on a parliamentary representative system, and became the first elected prime minister of Egypt.

As architectural proof to the growing metaphoric significance of the Pharaonic past for Egyptian nationalists, upon his death, Zaghlul was buried in a neo-Pharaonic tomb that takes up a city block in one of Cairo's districts (Wynn, 2007). Under the parliamentary monarchy, Egypt cultivated a set of intellectuals who facilitated the democratic tone through a commitment to individual freedoms, secularism, and faith in science. This period became viewed with liking by future generations as the Golden Age of Egyptian liberalism that prioritized the state's interests (Jankowski, 1970). Egyptian liberals today are all but individuals advancing ideas pushed forward by Zaghlul and his counterparts. Hamzawy's ideas for example are prime illustrations of this ideological inheritance, which is evident in his advocacy for a comparable replica of the parliamentary system accomplished by the Wafd Party in 1923.

The secular narrative on the other end was instigated during Muhammad Ali's Egypt, when military drafting shifted to the fellahin, who viewed it as an opportunity for 
vertical mobility if they were unable to pursue the scholarly route. For Ali, the recruitment was an ethnic cleansing of his borders after his seizure of Egypt, since an indigenous army was needed to replace the traditional Ottoman mercenary. Thus, dedicated technical facilities were set up with rigorous training systems to instill a sense of reverence for rule of law into the fellahin, who served for three years but were branded soldiers for life. The fellahin were not fond of military life and its terms, yet the process transformed them into methodical soldiers (Fahmy, 1997; Sayyid-Marsot, 1984). In the years to follow, the oppressive measures burdening the soldiers, the utmost discontent with Ali's successors and their lavish living, and the perturbed parliamentary rule undermined the faith in the king and the liberal experiment, planting the military's political interpolation.

Gordon (1992) quote's the soldiers' critical impression of the king's life, saying:

He [the king] sleeps on ostrich feathers, immersed in silk. If the Egyptian people could visit the Sirag al-Din palace they would immediately realize what an enormous lie proclaims Sirag al-Din leader of the people. The man who lives in the likes of this palace can be nothing other than the enemy of the people. Gold on the walls, gold on the staircases, gold in the ceiling, gold on the tables and desks, gold, gold everywhere. (p.28)

Gamal Abdel Nasser (the second president of Egypt) reflects in an interview with the Sunday Times about his youth before becoming an officer saying, "I entered jail as an enthusiastic student and left fraught with rage. A long time passed before my ideas, beliefs and plans took shape but even at that early stage, I knew my country was embroiled in a continuous struggle for freedom." (Morgan, 1962, paras.6). Nasser was interested in Arab literature by Tawfiq Al-Hakim, such as Return of the Spirit, about the emergence of an Egyptian leader who will unite Egyptians and fight for the revival of 
their national spirit (Osman, 2011; Reid, 2015). As a result, an underground movement termed the "free officers" was triggered (Cook, 2011, p. 44; Gordon, 1992) and launched a successful revolt in 1952 demanding that the king and the British leave Egypt. Nasser, through Nasserism, favored a Pan-Arab identity that allowed him to challenge Iranian and Saudi attempts at regional leadership on the basis of a Pan-Islamic identity (Wynn, 2007).

Yet Pharaonic nationalism would come to accompany Pan-Arabism under president Anwar Sadat, who often referred to Egypt's ancient Pharaonic heritage in his speeches, calling himself "the last of the pharaohs" (Wynn, 2007, p. 166). By the time of his death, a biographer of Sadat wrote, "For the first time the people of Egypt had killed their Pharaoh" (Wynn, 2007, p. 166), while Sadat's assassins gleefully shouted, "We have killed Pharaoh!” (Wynn, 2007, p. 166), illustrating the ambivalence with which some Egyptians regard their Pharaonic past (Wynn, 2007). During the Mubarak era, Mubarak's nonmilitary son and his elite business friends weakened his position as a military representative. His catchall approach diluted Pan-Arabism, and as Salem (2013) highlights, the introduction of neoliberalism hindered the military's status and national agendas. Salem (2013) argues that this explains the military's strategic decision to side with the protestors during the 2011 revolution and its return to power in 2014. Morsi's 2013 ousting and Al-Sisi's return to the power seat in 2014 are without a doubt a simulated victory to the 1952 revolt.

For the Islamist narrative, its Pan-Islamism ideology sprung and gained its terminology from a newspaper that affirmed a union among Muslims superior to national identities: Al-Urwa al-Wuthqa newspaper (Ahmed, 1960). In this religious awakening, 
while some Al-Azhar students remained servants of the evolving state (Sufis),

independent students who were displeased with the university's passive stance against Egypt's emancipation, branched into other forms of Pan-Islamist movements. The Salafist movement became one that was mostly concerned with restrictions on practice and shied away from political involvement. On another end, the more politically active Hassan al-Banna launched his education at a rural religious school, where he enriched his theological training (Mitchell, 1960). His religious activism is reflected in Mitchell's (1960) tale in which Al-Banna attempts to have an invasive statue of a "semi-naked" woman confiscated by authorities (p. 16). He joined several religious groups, such as "The Society for the Prevention of the Forbidden," for naming moral offenses of those regarded as living in defilement of Islam (Mitchell, 1960, pp. 12-13).

Al-Banna perceived the social liberation of Egypt and British presence as attacks on Islamic orthodoxy weakening the influence of religion (Mitchell, 1960). He wept in response, saying, "No one but God knows how many nights we spent reviewing the state of the nation, analyzing the sickness of the thinking and the possible remedies, so disturbed were we that we reached the point of tears" (Mitchell, 1960, p. 17). In 1928, the Muslim Brotherhood idea sprung with a foundation that is reflected in the group's renowned slogan "Islam is the solution"- - a belief that a return to Islamic Egypt would eradicate the injustices bestowed by colonization. Al-Banna preached:

Islam requires that the Muslim community unite around one leader or one head, the head of the Islamic State, and it forbids the Muslim community from being divided among states... The Muslim Brotherhood puts the idea of the caliphate and work to restore it at the forefront of its plans. (Mitchell, 1960, p. 17) 
The organization grew from 800 members in 1936 to 200,000 by 1938, and over 2

million by 1948, but was banned after being accused of homicides against the British. Nevertheless, they continued subversive activity through the 1950s and aided the 1952 coup d'état by the Free Officers in the hopes of Islamizing Egypt. After the coup, Nasser imprisoned thousands of Brotherhood members, blaming them for an attempt on his life (Bannā, 1978; Mitchell, 1993).

In 2001, a document dated 1982 outlined a worldwide strategy for Islamic policy for the Brotherhood and inspired the writing of a book titled La conquête de l'Occident: Le projet secret des Islamistes (The Conquest of the West: The Islamists' Secret Project) by Sylvain Besson (“The Muslim Brotherhood 'Project,"” 2016). In those years, the Brotherhood combated what it called the current US-led war against Islamic identity, forcing the Ministry of Culture to ban the publication of three novels, arguing they endorsed blasphemy (Bradley, 2008). This history explains the group's 2005 political platform and explains the Islamists' hurdle to dominate the writing of the constitution in 2012.

These three conflicting examples of counter national ideologies acted as mechanisms that serve the modern-day conviction of self-realization within the Egyptian nation-state. This self-realization is based on the continuance of past identities that manifest themselves through opinions on modern-day norms and rules that develop national unity; the battle surrounding Article II in 2011 is a prime example of that. Moreover, these views as shown where not unique to the 2011 political scene; each narrative in 2011 was predisposed with its own views on statehood and its own views of the other. 
During a speech in 2014, Al-Sisi acknowledged one side of this notion of a longstanding struggle, saying, "Egypt had suffered from the scourge of terrorism since the 1920s" ("His Excellency Abdel Fattah Al Sisi, President," n.d.), referring to the emergent years of the Muslim Brotherhood. During those times, Lutfi al-Sayyid also wrote:

The idea of an Islamic unity might occur to some who are not seriously engaged in politics...Pan-Islamism has long been with us as a conception which comes out...whenever Egyptians see European statement acting in concert against Egyptian interests...they tend to contract their fortune with that of the Balkan domains of the Ottoman Empire. They conclude that these dependencies have won their independence... because their inhabitant are Christians...that there is a certain type of unity among the Christians in Europe...consequently they wish for a unity among Muslims....As Christians unity saved the Balkan countries from yoke of the Muslim Ottomans, Muslim unity would save Egyptians from European Hegemony. This, we believe, is a naïve idea engendered by a faulty understanding of European politics in the East. (Ahmed, 1960, p. 61)

During 1952, the prime ministry cabinet included an associate of the Muslim Brotherhood who Cook (2011) says was "a far more controversial selection that would have repercussions for Brotherhood-Free Officer relations down the road" (p. 46). Mitchell (1960) describes that his dissertation research during Nasser's time was "sporadically curtailed, often enriched and always complicated by the growing pains of a revolutionary government, increasing tensions between this military government and the Muslim Brothers" (p. xxvi). He defines the tension as "a cleavage with in the society" (p.2), with the two groups struggling to hold power. Nasser also clashed with liberal leader Mustafa al-Nahhas, when he wanted to retire old parliamentary front-runners in favor of a new cohort of politicians (Mitchell, 1960, pp. 48-49).

After Nasser, the Brotherhood clashed and assassinated Sadat after he signed the peace treaty with Israel (Ibrahim, 1982). During Mubarak's Egypt, in an article titled "In Egypt the Real Struggle Is Between Mubarak and the Brotherhood,” a Brotherhood 
member said, "No one knows for sure how many political prisoners the Mubarak government holds behind bars...maybe 50,000” (Halsell, 1996, para. 1). In Mubarak’s 1995 Brotherhood crackdown, police charged some with "directing an illegal organization aiming to impede the rule of law and the constitution" (Halsell, 1996, para. 5). Virginia Sherry, director of Middle East affairs for the New York-based Human Rights Watch, said, “It's not related to political violence. It appears to be an assault on political opposition across a broad spectrum" (Halsell, 1996, para. 5). Another Brotherhood member said, "Mubarak's government is pressing people toward desperation, terrorism will be the only way for change" (Halsell, 1996, para. 6). A 74year-old Brotherhood spokesperson imprisoned for 7 years said, "My crime was simply the way I thought...Here in Egypt...we all meet in the prisons" (Halsell, 1996, paras. 11, 20).

In concluding the analysis and the discussion, the 2011 conflict ought to be viewed as a snippet of a long-standing rivalry amid the three master-narratives - an enduring conflict around governing matters that are in essence allegorical components of conflicting fabricated sole identities for Egypt. These absolute nationalistic attempts create an entwining never-ending conflict because of the ambiguity surrounding the consistency of Egyptian identity through decades of external influences. These attempts are fueled by the nationalistic myth that puts forward the notion of a continuing historical narrative of the nation as descendants and heirs to the homeland of their ancestors, whom they share a common fate and an unceasing legacy.

This reckons the verdict of an absolute resolution for the definition of modern Egyptian national identity an unconceivable and nebulous expedition, and an illogical 
route to pursue in resolving this modern day dilemma. With that, today's fabricated absolute modern day Egyptian identities ought to reflect on the fact that they have more in common amongst themselves than they do with whom they claim ancestry; they ought to reflect on finding the crosscutting Egypt within the divided one. These ideas raise fundamental question about an alternative method for resolution, particularly after the convolution brought on by the additional layers of violent exchanges and the ensued grievances. 


\section{Chapter 5 \\ Conclusions and Recommendations}

The protracted reenactment of a consistent struggle has wedged Egyptians in looping waves of debate due to the absence of prospects to engage in dialogical ventures that may foster an understanding of the nature of modern Egyptian national identity. Demonstrated by the analysis, even when dialogue was presented, it was arrogantly refused by both the constitution opposing parties in 2012 and the Brotherhood's presidency in 2013. This arrogance is also verified in the tit-for-tat competitive nature amid the three master-narratives, in how the actions of one group became a consequence of another group's preceding actions. This sheds light on a pattern of historical escalation that has resulted in a heap of complex grievances that continued to rise with every conflict wave. This arrogant behavior is a crosscutting notion embedded in the conflict styles of the three master-narratives, and comes as no surprise given the nation's traumatizing history of conqueror subjectivity.

As mentioned in the literature review of this thesis, in defining arrogance, I explained how individuals displaying it are usually attempting to veil feelings of inferiority. In Egypt's case, decades of conquest have created traumatizing feelings of inadequacy, due to the superiority of the colonizer over the colonized. Alongside the corruption and oppression of postcolonial dictatorships (a reincarnation of imperialism itself), this suppression gave rise to the arrogant behavior that infuses Egyptian conflict styles. These behaviors foster a rigid mind and block people's "receptors of change" and new thinking, because they transform all dialogical attempts into futile debates that subsequently lead to violence and utter mistrust (Bassett, 1994; Fisher \& Sharp, 2004). 
However, in recommending processes of conflict resolution for the outcomes of this thesis, on one end I looked into research Oliver Ramsbotham's work, which seeks to understand why conflict resolution methods are sometimes ineffective in resolving such intractable conflicts. He suggests that one of the main reasons for this failure is due to people engaging in what he calls "radical disagreements." Ramsbotham defines radical disagreement in many ways, such as "conflicting perceptions" and "embattled beliefs", and explains that they are disagreements in which people do not see conflicting opinions as two varying perception of truth. Instead, he says, they attempt to present their worldview as the sole true perspective. He argues that acknowledging both the existence of a radical disagreement about truth and the distance resulted between the conflicting parties is key to dealing with the problem (Ferguson, 2012).

Ramsbotham hence sets out to promote what he calls a "dialogue of strategic engagement," which is a part of the natural conflict dynamic, argumentative and intense, instead of a dialogue for mutual understanding. He argues that when conflicts are highly intractable conflict actors are not ready to explore common ground, but in place of silence, argumentative dialogues may allow all sides to gain a better insight into the depth of the disagreement. They also offer the opportunity for thoughts to be uttered by one side that grasps the attention of the other side, which may cause an opening to additional constructive communication (Ferguson, 2012). This relates to other works by Ramsbotham regarding the theory of "contact" between divided communities. He explains that in the course of a radical disagreement not everyone within the same narrative is a hardliner, and sheds light that there is some who can be considered moderates within their narratives. Hence, any type of contact can act as a passageway to 
identify such individuals that later can be recruited for a more productive dialogue around areas of common interest (R. Cunliffe, personal communication, 2015). This work suggests that there could be some form of argumentative dialogue that could work as a starting point of recruitment for a long-term resolution process.

On another end, in order to further understand the role of arrogance, I referred to Tracy and Prehn's (2011) analysis of "pride in context", which explains two facets of pride that "through expression, experience, and motivational impact on behavior function to promote a distinct behavioral repertoire for attaining status" (p. 1). The authors argue for a distinction between status earned through socially valued skills (self-confidence) and status forcibly taken by intimidation and dominance (arrogance) (Tracy \& Prehn, 2011). Arrogance therefore can be viewed as a state of low self-confidence, or selfdistrust.

\section{Two Levels of Distrust}

With the above premises in place, it can be concluded that there are two levels of trust building needed as part of the resolution process and for positive dialogue to take place, trusting others and self-trust. It also indicates that the resolution process may need to be a multi-stage and a multi-level process. Argumentative dialogue as the initial stage, while acting as a tool for recruitment for positive dialogue, may also create an opportunity for trust. This initial stage maybe risky and perhaps unsuitable, but it may create an opportunity for trust building for the following stage. The following stages should focus on building both trust and self-confidence.

In relation to positive dialogue in particular, self-confidence promotes respect for protocols, invites the opinion of experts, and is more likely to help individuals realize 
their interdependence as members of society. Confidence assures the individual that the utilization of experts, respect for regulations, and listening to conflicting views does not lessen one's own abilities, and often heightens rational thinking. Self-confidence also has bearing on the willingness to reconcile, which is essential, as true reconciliation occurs when parties wield determination to rebuild the damaged relationship. Thus, by replacing arrogance with confidence, we are also taking the initial step in building further trust amid the three master-narratives, and hence positive dialectical approaches have a higher chance of being effective (Lewicki, McAllister, \& Bies, 1998; Lewicki \& Tomlinson, 2003; Rousseau et al., 1998).

\section{Conflict Resolution Training}

Bearing in mind Feller and Ryan's (2012) eight core traits in the makeup of effective dialogical approaches, the process of designing a positive dialogue can begin at the pre-dialogue stage by injecting a culture of conflict resolution into Egyptian society on the top, middle, and grassroots levels, as also described in Lederach's (1997) Building Peace. This is particularly what I meant by a multi-layered resolution process, in which interveners creatively construct an incentive to aid in the emergence, attraction, and support of the correct minds for involvement simultaneously as the argumentative dialogues are taking place. While collective approval is not the objective at this stage, the purpose is the reeducation at key levels of society through voluntary training seminars for ideologically assorted hardliner accomplices, key government representatives, business and societal figures, and youth organizations. These conferences should to teach encounter skills with which to analyze conflict, recognizing and articulating emotions, 
highlighting the colossal benefits of heighten living circumstances in conflict-free zones, and the benefits of dialectic forms (Abu-Nimer, 1999).

\section{Building Self-Confidence and Trust}

On another layer, the outcomes from these conflict resolution training conferences and argumentative dialogues can be used to enroll a pool of ideologically diverse individuals in peace-building cooperative projects that focus on building self-confidence and coexistence. These types of projects are suitable for top, middle, and grassroots levels, and may aid in the emergence of primed individuals for positive dialogue recruitment on all three master-narrative levels. If designed correctly, individuals can build selfconfidence through overcoming certain challenges and accomplishing targeted goals, while also building trust of each other by confronting indifferent parties and working as teams. The projects however must encompass two major elements. One, they must be short-term in order to cater to the instant-gratification nature of the Egyptian community and in order to reduce risks. Two, they must target simple communal goals, in order to minimize the risk of failure, since an unsuccessful project would accomplish the exact opposite of its intentions.

Below I propose some ideas with the understanding that they need careful review and design; works-in-progress that can be developed to accomplish the above trustbuilding goals. One project for example is to create a national high-quality product made out of $100 \%$ Egyptian materials, from farm to retail, which may instill a sense of national confidence, especially if it earned the respect of the international community. Another project is to establish a mentorship program at the elementary and university levels that targets building self-trust and self-confidence connecting students' education with real 
life prospects. More project ideas could center on educational workshops designed to reeducate the public about Egyptian history in such a way that highlight how Egypt evokes home for all three master-narratives. Other projects ideas may include: a coastal rescue project; garbage-cleaning project; a community farms and gardens project. These selfconfidence and trust-building projects are the first step in further targeting and educating the moderates within each master-narrative, and thus increasing the chance of recruiting flexible mindsets and newfangled faces who can deconstruct the assumptions engraved by status quo agents.

\section{Designing Positive Dialogue}

When positive dialogue is then suggested, selecting a safe space for the talks to take place is also a key element. Incorporating the movement trait advised by Feller and Ryan (2012), a place such as Cyprus can be best fitted for its neutrality regarding the conflict, its proximity to Egypt, its own history of successfully utilizing dialectic structures, and its multiethnic and multi-religious composition that can be seen as a comparison to Egypt's own struggle. In addition, resemblances between Cypriot and Egyptian culture and weather can generate a consoling environment for Egyptians to speak their minds. Another key component is a mediator that clasps religious and political knowledge, one who can use terminology that appeals to all sides equally. An Egyptian native, familiar with Egyptian national jargon and colloquial dialects, with a scholarly accredited education in peace and conflict resolution, along with a deep understanding of political, economic, and Islamic Sharia law, may be a seamless candidate. 
Facilitators that lack Egyptian nationality and Islamic background may be viewed as an infringement on Egyptian national affairs, and would fall short of the advantage of technically arguing political issues while simultaneously drawing from spiritual law to find alternatives to rigid interpretations of Quranic literature. This brings about the final element of my suggested dialogue structure, which is the topics of discussion. The topics of discussion ought to be centered on the overall benefit and initially shy away from controversial topics such as the constitution, Israeli-Egyptian relations, and Egyptian identity. With a focus on issues that involve Egypt's economic, environmental, and social health that are in essence "superordinate goals", older notions of enemy images may begin to shatter and fade. When older concepts begin to disappear, conversations may then slowly shift to topics directly related to the period between 2011 and 2014 .

\section{A Final Note}

In closing, futuristic paths cannot be free of realizing spaces for coexistence; Egyptians must face the question of how multi-ideological nations can cohabitate and thrive, an inescapable truth. Today, the conflict has imposed higher limitations on all sides than in the past; the Egyptian community ought to learn from the burdening outcomes of hard power and from how rigidity taxes its own groups' interests. These notions should be substituted with awareness that national identity is boundless, fluid in nature, and ever changing, because it is constantly being assembled from a repertoire of constituents (Hammoudi, 2002). In view of that, when contemplating Egyptian national identity, the inquiry should not to be whether Egyptians consider themselves Arabs, Muslims, Christians, democrats, or conservatives, it should be a triumphant embracement 
of Egypt's diverse construct and their crosscutting links in a manner as momentous in uniqueness as are its great pyramids.

I was reminded of these two sentiments as I was researching for this thesis, when I came across Lisa Wynn's (2007) Pyramids and Nightclubs, an examination of how cross-cultural encounters elucidate the contradictory definitions of Egypt. The book triggered me to reflect on my time spent living in the United States, on how conversations about Egypt brought to mind golden deserts and monumental pyramids for those interested in its history and ongoing clashes and bewildering chaos for those following current events. Yet, ancient civilization and a modern-day conflict that has gained worldwide traction were conversational starters naturally occurring for a foreigner to Egypt. The book reminded me that, for a native like myself, Egypt evokes home, my place of childhood joy and comfort; the place where I woke up for a late breakfast of $f u l$ medames (fava beans) before bathing in the turquoise waters of Alexandrian seashores. I had forgotten how stratums of Egyptian society gather at sundown at the Cornish, when the surface of the ocean and the Nile glimmer with the reflections of elegant hotels and international boutiques alongside the modest neon shop signs and local food carts. In that Egypt, you ride the night after an evening stroll—some go to eateries, some go to nightclubs, and some go to mosques. You mingle with friends and family and then head home close to sunrise, getting a glimpse of the pyramids on the horizon, a romantic backdrop to the country's modern-day makeover Wynn says (Wynn, 2007).

In the initial stages of my research, this collocation of ancient against modernity intrigued me in the sense of how Egypt has succeeded in holding on to its association with past epochs within the molding of contemporary nation-states. However, it was not 
the furtherance of technological, medicinal, or militaristic achievements of past epochs that intrigued me - after all, Egypt is a third-world country — but more the primordial symbolic essence of prominence. I was aware that modern Egypt produced some political, scientific, and artistic greatness, with Mohamed ElBaradei, the Egyptian diplomat; Naguib Mahfouz, an Egyptian writer; and Ahmed Zewail, an Egyptian scientist, receiving the Nobel Prize in honor of their work. Yet, thus far, in comparison with Pharaoh Egypt, I knew that today's Egypt suffers from a social gulf fashioned by a deterioration in the quality of citizen life, large economic disparities, and contesting ideologies about its defining elements, ideas at the core of my inquiry.

Nevertheless, Wynn's reflection made me realize that most Egyptians would approve that the Egypt I recall above is a crosscutting notion cherished by the hearts of those from all layers of its society today. "Fava bean Egypt" has no socioeconomic or ideological boundaries; whether at one of Egypt's finest hotels or in Egypt's "random building" communities, alashwaeyat, you are guaranteed the same tasty helping of Egyptian fava beans. The customary breakfast has become something of a national dish. Ful medames is believed to be, according to the saying "Beans have satisfied even the Pharaohs" (Roden, 2000, p. 328), the food of the Pharaohs. Researcher Layla Eplett even wrote that Pharaoh Ramses III presented thousands of fava beans in jars to the Nile god, and Egyptians excitedly tell how the beans have been found imprinted on Pharaonic tombs (Chambers, 2014). Ironically, I also realized that fava bean brunches in and of themselves are among the many self-constructed notions of the modern Egyptian nation. Still, all layers of society eat them notwithstanding the truthfulness of their ancestrypassing claim. 
Thus, even from a metaphorical stance, one realizes that there is in fact a traversing Egypt within the divided one. Both the rich and the poor, the secular and the religious, will delightedly converse about their favored fava recipe. Perhaps this is because Fava beans as a topic and shared communal aspect remains debate-free, and as such, symbolizes hope for Egyptians' willingness to share communal aspects of Egypt's modern day defining elements. 
References

Abdel Kouddous, Sharif. (2013, October 1). What happened to Egypt's liberals after the coup? The Nation. Retrieved from https://www.thenation.com/article/whathappened-egypts-liberals-after-coup/

Abdellatif, R. (2013, December 8). Egypt protesters demand that Mohamed Morsi step down. Los Angeles Times. Retrieved from http://articles.latimes.com/2012/dec/08/world/la-fg-egypt-rallies-20121208

Abu-Nimer, M. (1999). Dialogue, Conflict Resolution, and Change Arab-Jewish Encounters in Israel (SUNY Series in Israeli Studies). Albany: State University of New York Press.

Abu-Rabi', I. (1988). Al-Azhar Sufism in modern Egypt: The Sufi thought. Islamic Quarterly, 32(4), 207.

AFP. (2011, April 30). Egypt's Islamists announce own political. Dawn. Retrieved from http://www.dawn.com/news/625028/egypts-islamists-announce-own-politicalparty

AFP. (2013, July 8). Seized Egyptian soldiers escape. Aljazeera. Retrieved from http://www.aljazeera.com/news/middleeast/2013/07/20137891839289850.html

Ahmed, J. (1960). The intellectual origins of Egyptian nationalism. London: Oxford University Press.

Ajami, F. (1974). On Nasser and his legacy. Journal of Peace Research, 11, 41-49. doi:10.1177/002234337401100104

Alaa al-Aswany. (n.d.). Retrieved from http://www.worldaffairsjournal.org/users/alaa-alaswany

Albo, M. (2012). Al-Azhar Sufism in post-revolutionary Egypt. Journal of Sufi Studies, $1(2), 224-244$.

Al-Youm, A.-M. (Trans.). (2013a, February 7). Latest wave of resignations as Cabinet, presidency spokesmen quit. Egypt Independent. Retrieved from http://www.egyptindependent.com/news/latest-wave-resignations-cabinetpresidency-spokesmen-quit

Al-Youm, A.-M. (Trans.). (2013b, October 10). Interview with defense minister Abdel Fattah Al-Sisi. Egypt Independent. Retrieved from http://www.egyptindependent.com/node/2196186

Ali, A. (2011, February 18). 'The Quran is our law; jihad is our way'; for a sense of the kind of Egypt the Muslim Brotherhood wants, start with its motto. The Wall Street Journal Eastern Edition, p. A13.

Amr Hamzawy. (n.d.). Retrieved from http://carnegieendowment.org/experts/237

Anastasiou, H. (2008). The broken olive branch: Nationalism, ethnic conflict, and the quest for peace in Cyprus (1st ed., Syracuse studies on peace and conflict resolution). Syracuse, NY: Syracuse University Press.

Anastasiou, H. (2007). "The Communication Imperative in an Era of Globalization: Beyond Conflict-Conditioned Communication," Global Media Journal: Mediterranean Edition. Vol. 2, no. 1, 63-75.

Anastasiou, H. in Hedges, C. (2003). War is a force that gives us meaning. Chapter 2, p. 45, New York: Anchor Books. 
Associated Press. (2012a, December 8). Egypt: Military warns of "disastrous consequences." CBSNews.com. Retrieved from http://www.cbsnews.com/news/egypt-military-warns-of-disastrous-consequences/ Associated Press. (2012b, December 25). Egyptian voters approve new constitution, but low voter turnout means the country's troubles are far from over. NY Daily News. Retrieved from http://www.nydailynews.com/news/world/egypt-yes-newconstitution-article-1.1227138

Associated Press. (2013, July 3). Egypt timeline: From revolution to the current crisis. The Telegraph. Retrieved from http://www.telegraph.co.uk/news/worldnews/africaandindianocean/egypt/101568 02/Egypt-timeline-from-revolution-to-the-current-crisis.html

Atlantic Council. (2013). Translation: President Mohamed Morsi's address to the nation. Retrieved from http://www.atlanticcouncil.org/blogs/menasource/translationpresident-mohamed-morsi-s-address-to-the-nation

Azhar Grand Sheikh again rejects modifications to Article II. (2011, March 21). Egypt Independent. Retrieved from http://www.egyptindependent.com/azhar-grandsheikh-again-rejects-modifications-article-ii/

[Bakri: Morsi governs without censorship or constitution]. 2012. Retrieved from:

http://www.karamapress.com/arabic/index.php?Action=PrintNews\&ID=19068

Bannā, H.. (1978). Five tracts of Hasan Al-Bannā' (1906-1949): A selection from the Majmū 'at rasā'il al-Imām al-shahīd Hasan al-Bannā' (C. Wendell, Trans.). Berkeley: University of California Press.

Bar-Tal, D. (2004). Nature, Rationale, and Effectiveness of Education for Coexistence. Journal of Social Issues, 60(2), 253-271.

Bassett, T. J. (1994, July). Cartography and empire building in nineteenth-century west Africa. Geographical Review 84(3), 316-335. Retrieved from http://www.jstor.org/stable/215456

Beaumont, P. (2012, December 26). Mohamed Morsi signs Egypt's new constitution into law. The Guardian. Retrieved from https://www.theguardian.com/world/2012/dec/26/mohamed-morsi-egyptconstitution-law

Behn, S. (2013, July 19). Pro-Morsi protestors pack the streets of Cairo. VOA News. Retrieved from https://www.voanews.com/a/egyptian-security-forces-on-standbyas-protests-heat-up/1705168.html

Bisgaard-Church, E. (2011). Egyptians campaign for independence, 1919-1922. Retrieved from http://nvdatabase.swarthmore.edu/content/egyptians-campaignindependence-1919-1922

Blackman, W. (2000). The fellahin of Upper Egypt. Cairo, Egypt: American University in Cairo Press.

Bowman, A. (1989). Egypt after the pharaohs, 332 BC-AD 642: From Alexander to the Arab conquest. Berkeley, CA: University of California Press.

Bradley, J. (2008). Inside Egypt: The land of the pharaohs on the brink of a revolution (1st ed.). New York, NY: Palgrave Macmillan. 
Brotherhood begins campaigning without religious slogan. (2011, October 19). Egypt Independent. Retrieved from http://www.egyptindependent.com/news/brotherhood-begins-campaigningwithout-religious-slogan

Brown, J. (2011, December 20). Salafis and Sufis in Egypt. Retrieved from http://carnegieendowment.org/2011/12/20/salafis-and-sufis-in-egypt-pub-46278

Brown, R., \& Hewstone, M. (2005). An integrative theory of intergroup contact. Advances In Experimental Social Psychology, Vol 37, 37, 255-343. (http://www.sciencedirect.com/science/article/pii/S0065260105370055)

Brugman, J. (1984). An introduction to the history of modern Arabic literature in Egypt. Leiden: E. J. Brill.

Bulliet, R. (2002). The Crisis within Islam. The Wilson Quarterly (1976-), 26(1), 11-19.

Burton, J. (1990). Conflict : Resolution and prevention (Conflict series). New York: St. Martin's Press.

Cauthen, B. (2004). Covenant and Continuity: Ethno-Symbolism and the Myth of Divine Election. Nations and Nationalism, 10(1-2), 19-33.

Childress, S. (2013). Timeline: What's happened since Egypt's revolution? Retrieved from http://www.pbs.org/wgbh/frontline/article/timeline-whats-happened-sinceegypts-revolution/

Cleveland, W. (2004). A history of the modern Middle East (3rd ed.). Boulder, CO: Westview Press.

Coleman, P., \& Deutsch, M. (2015). Morton Deutsch: A pioneer in developing peace psychology. New York, NY: Springer.

Constitutional history of Egypt. (n.d.). Retrieved from http://www.constitutionnet.org/country/constitutional-history-egypt

Cook, S. A. (2011). The struggle for Egypt: From Nasser to Tahrir Square. New York, NY: Oxford University Press.

Death toll from Egypt violence rises to 638: Health ministry. (2013, August 15). Ahram Online. Retrieved from http://english.ahram.org.eg/NewsContent/1/64/79160/Egypt/Politics-/Death-tollfrom-Egypt-violence-rises-to--Health-mi.aspx

Deutsch, M. (2001). Cooperation and conflict resolution: Implications for consulting psychology. Consulting Psychology Journal: Practice and Research, 53(2), 7681. Retrieved from http://dx.doi.org/10.1037/1061-4087.53.2.76

Deutsch, M., \& Coleman, Peter T. (2000). The handbook of conflict resolution : Theory and practice (1st ed.). San Francisco, Calif.: Jossey-Bass.

Ding, S. (2011, March 25). Players in the debate over amending Article 2 of the Egyptian constitution [Blog post]. Retrieved from

http://islamopediaonline.org/blog/players-debate-over-amending-article-2egyptian-constitution

Dingley, J. (2011). Sacred communities: Religion and national identities. National Identities, 13(4), 389-402.

د دمز اوي بمحافظة الأقصر لماذا أعترض على . DrAmrHamzawyOfficial. (2012, December 20) د. Hamzawy at Luxor Governorate Why I object to the مشروع الدستور؟؟ الجزء الثالث 
draft constitution? Part Three]. Retrieved from https://www.youtube.com/watch?v=V7XsoqJi0GQ\#t=146

Dunne, M. (2013, November 25). The revival of secular dissent in Egypt. Retrieved from http://carnegieendowment.org/2013/11/25/revival-of-secular-dissent-in-egyptpub-53694

Dziadosz, A. (2013, July 3). Egypt's Brotherhood will not use violence: Senior leader. Reuters. Retrieved from http://www.reuters.com/article/us-egypt-protestsreaction-idUSBRE9621F720130703? feedType $=$ RSSM

Dziadosz, A., \& Nasralla, S. (2013, July 8). At least 51 people were killed in Egypt as Islamists urge defiance. Reuters. Retrieved from http://www.reuters.com/article/us-egypt-protests-idUSBRE95Q0NO20130708

Egypt. (September 24). retrieved from https://www.un.org/en/ga/69/meetings/gadebate/24sep/egypt.shtml

Egypt: Abdul Fattah al-Sisi profile. (2014, May 16). BBC News. Retrieved from http://www.bbc.com/news/world-middle-east-19256730

Egypt crisis: Army ousts President Mohammed Morsi. (2013, July 4). BBC News. Retrieved from http://www.bbc.com/news/world-middle-east-23173794

Egypt referendum strongly backs constitution changes. (2011, March 20). BBC News. Retrieved from http://www.bbc.com/news/world-middle-east-12801125

Egypt unrest: Morsi marchers die as army fires. (2013, July 5). BBC News. Retrieved from http://www.bbc.com/news/world-middle-east-23202096

Egypt's Mohammed Morsi defiant as protest deaths rise. (2013, July 3). BBC News. Retrieved from http:/www.bbc.com/news/world-middle-east-23154233

Egyptian constitution "approved" in referendum. (2012, December 23). BBC News. http://www.bbc.com/news/world-middle-east-20829911

Egyptian.Armed.Forces.Admins. (2013, July 2). Final hours . Retrieved from https://www.facebook.com/Egyptian.Armed.Forces.Admins/posts/633415760005 031

Egyptsource. (2014, March 27). Translation of Abdel Fattah al-Sisi's resignation speech. Retrieved from http://www.atlanticcouncil.org/blogs/menasource/translation-ofabdel-fattah-al-sisi-s-resignation-speech

Eldem, E. (2013, October 4). Balancing Sharia: The Ottoman Kanun. BBC. Retrieved from http://www.bbc.co.uk/religion/0/24365067

El-Houdaiby, I. (2012, July 29). The identity of Al-Azhar and its doctrine. Jadaliyya. Retrieved from http://www.jadaliyya.com/pages/index/6638/the-identity-of-alazhar-and-its-doctrine

Emig, R., \& Lindner, O. (Eds.). (2010). Commodifying (post)colonialism: Othering, reification, commodification and the new literatures and cultures in English. Amsterdam, Netherlands: Rodopi.

Emirates Center for Strategic Studies and Research. (2017). Mustafa Bakri profile. Retrieved from http://www.ecssr.com/ECSSR/print/prf.jsp?lang=en\&prfId=/Profile/Profiles_303 7.xml 
Fahmy, K. (1997). All the Pasha's men: Mehmed Ali, his army and the making of modern Egypt. Cairo, Egypt: American University in Cairo Press. Retrieved from http://www.jstor.org/stable/j.ctt15m7mvc

Fairclough, N., \& Ietcu-Fairclough, Isabela. (2012). Political Discourse Analysis : A Method for Advanced Students. Hoboken: Taylor \& Francis.

Fayed, S., \& Taylor, P. (2013). Egypt's President Mohammed Morsi rejects military's ultimatum, country on edge. Huffington Post. Retrieved from http://www.huffingtonpost.com/2013/07/02/egypt-mohammed-morsiultimatum_n_3532051.html

Feller, A. E., \& Ryan, K. K. (2012, Summer). Definition, necessity, and Nansen: Efficacy of dialogue in peacebuilding. Conflict Resolution Quarterly, 29(4), 351-380. doi:10.1002/crq.21049

Ferguson, N. (2012). Oliver Ramsbotham: Transforming Violent Conflict: Radical Disagreement, Dialogue and Survival. Democracy and Security, 8(2), 219-221.

Fisher, E., \& Sharp, S. W. (2004). The art of managing everyday conflict: Understanding emotions and power struggles. Westport, CT: Praeger.

Gasper, M. (2009). The power of representation: Publics, peasants, and Islam in Egypt. Stanford, CA: Stanford University Press.

Ghali, J. (Trans.). (n.d.). Egypt: Constitution of 1923. Retrieved from http://www.constitutionnet.org/sites/default/files/1923__egyptian_constitution_english_1.pdf

Ginat, R. (1997). Egypt's incomplete revolution: Lutfi al-Khuli and Nasser's socialism in the 1960s. London: Frank Cass.

Gordon, J. (1992). Nasser's Blessed Movement Egypt's Free Officers and the July revolution (Studies in Middle Eastern history (New York, N.Y.)). New York: Oxford University Press.

Halsell, G. (1996, January). In Egypt the real struggle is between Mubarak and the Brotherhood. Washington Report on Middle East Affairs, 14, 18.

Hamzawy, A. (2011a, February 25). What Egypt must do during transition. Retrieved from http://carnegieendowment.org/2011/02/25/what-egypt-must-do-duringtransition-pub-42768

Hamzawy, A. (2011b, March 7). Egypt: Evaluating proposed constitutional amendments [Blog post]. Retrieved from http://latimesblogs.latimes.com/babylonbeyond/2011/03/egypt-constitutionalamendments.html

Hamzawy, A., \& Fakir, I. (2012). Drafting Egypt's constitution. Retrieved from http://carnegieendowment.org/2012/11/15/drafting-egypt-s-constitution-event3867

Hearst, D., \& Hussein, A.-R. (2012, June 14). Egypt's supreme court dissolves parliament and outrages Islamists. Guardian. Retrieved from https://www.theguardian.com/world/2012/jun/14/egypt-parliament-dissolvedsupreme-court

Hendawi, H. (2012, December 23). Analysis: Egypt's Islamists tighten grip on power. U.S. News \& World Report. Retrieved from 
http://www.usnews.com/news/world/articles/2012/12/23/analysis-egyptsislamists-tighten-grip-on-power

Hendawi, H. (2013, July 11). Egypt's Christians face backlash for Morsi ouster. The Times of Israel. Retrieved from http://www.timesofisrael.com/egypts-christiansface-backlash-for-morsi-ouster/

His Excellency Abdel Fattah Al Sisi, President. (n.d.). Retrieved from http://www.un.org/en/ga/69/meetings/gadebate/24sep/egypt.shtml

Hoffman, M. (1979). Egypt before the pharaohs: The prehistoric foundations of Egyptian civilization (1st ed.). New York, NY: Knopf.

Hsieh, S. (1997). Rethinking the problem of postcolonialism. New Literary History, 28(1), 7-19. doi:10.1353/nlh.1997.0009

Hussein, A.-R. (2012, December 23). Egypt referendum: Opposition calls for fraud inquiry Cairo and agencies. The Guardian. https://www.theguardian.com/world/2012/dec/23/egypt-referendum-oppositionfraud-inquiry

Hussien, M. [Mohamed Hussien]. (2013, May 11). الفريق السيسى الجيش والثعب ايد واحده [General El Sisi The Army and the people are one Hand]. [Video file]. Retrieved from https://www.youtube.com/watch?v=cidge5ztGQE

Ibrahim, S. E. (1982). An Islamic alternative in Egypt: The Muslim Brotherhood and Sadat. Arab Studies Quarterly, 4(1/2), 75-93.

International Atomic Energy Agency. (n.d.). Biography of Dr. Mohamed ElBaradei. Retrieved from https://www.iaea.org/about/dg/elbaradei/biography

International IDEA (Trans). (2016). Egypt's constitution of 2014. Retrieved from https://www.constituteproject.org/constitution/Egypt_2014.pdf

Islam Elmasry. (2013, July 7). The final speech - President Muhammad Morsi - English [Video file]. Retrieved from https:/www.youtube.com/watch?v=U-1BD0ia700

Jankowski, J. (1970). The Egyptian blue shirts and the Egyptian Wafd, 1935-1938. Middle Eastern Studies, 6(1), 77-95.

Kambysellis, Z. (1997). Post-colonialism: The unconscious changing of a culture. Retrieved from http://www.postcolonialweb.org/poldiscourse/kz1.html

Khalil, M. (2006, March 10). Egypt's Muslim Brotherhood and political power: Would democracy survive? Retrieved from

http://www.discoverthenetworks.org/Articles/Egypts\%20Muslim\%20Brotherhood $\% 20$ and.html

Kingsley, P. (2013, October 29). Alaa al-Aswany on why he had to support Egypt's military crackdown. The Guardian.

https://www.theguardian.com/books/2013/oct/29/alaa-al-aswany-egypt-muslimbrotherhood

Kirkpatrick, D., \& Sheikh, M. E. (2012, December 31). For liberals in Egypt, a champion who quips. The New York Times, p. A4.

Koller, V. (2012). How to analyse collective identity in discourse: Textual and contextual parameters. Critical Approaches to Discourse Analysis Across Disciplines, 5(2), $19-38$. 
Kortam, H. (2012, November 27). Strong Egypt takes a separate stand. Daily News Egypt. Retrieved from http://www.dailynewsegypt.com/2012/11/27/strong-egypt-takesa-separate-stand/

Kortam, H. (2013, February 26). NSF to boycott elections, unsurprisingly. Daily News Egypt. Retrieved from http://www.dailynewsegypt.com/2013/02/26/nsf-toboycott-elections-unsurprisingly/

Kriesberg, L. (2003). Constructive conflicts: From escalation to resolution (2nd ed.). Lanham, Md.: Rowman \& Littlefield.

Kriesberg, L. (2003)."Identity Issues." Beyond Intractability. Eds. Guy Burgess and Heidi Burgess. Conflict Information Consortium, University of Colorado, Boulder. Posted: <http://www.beyondintractability.org/essay/identity-issues $>$.

Lederach, J. (1997). Building peace : Sustainable reconciliation in divided societies. Washington, D.C.: United States Institute of Peace Press.

Legal research guide: Egypt. (2015). Retrieved from https://www.loc.gov/law/help/legalresearch-guide/egypt.php

Levinger, M., \& Lytle, P. (2001). Myth and mobilisation: The triadic structure of nationalist rhetoric. Nations and Nationalism, 7(2), 175-194.

Lewicki, R. J., McAllister, D. J., \& Bies, R. J. (1998). Trust and distrust: New relationships and realities. Academy of Management Review, 23(3), 438-458.

Retrieved from http://www.jstor.org/stable/259288

Lewicki, R. J., \& Tomlinson, E. C. (2003a, December). Distrust. Retrieved from http://www.beyondintractability.org/essay/distrust

Lewicki, R. J., \& Tomlinson, E. C. (2003b, December). Trust and trust building. Retrieved from http://www.beyondintractability.org/essay/trust-building

Linton, E. (2012, December 23). Egypt constitution passes despite vote fraud claims. International Business Times. Retrieved from http://www.ibtimes.com/egyptconstitution-passes-despite-vote-fraud-claims-964052

Lynch, S. (2013, July 14). Egyptian military has 60-year record of running politics. USA Today. Retrieved from http://www.usatoday.com/story/news/world/2013/07/14/egyptian-military-longrole-in-politics/2514239/

Mackell, A. G. (2013, July 4). Morsi’s post-coup speech translated [Blog post]. Retrieved from https://austingmackell.wordpress.com/2013/07/04/morsis-post-coup-speechtranslated/

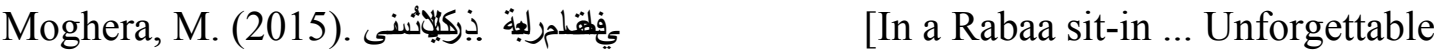
Memories]. Retrieved from http://www.huffpostarabi.com/ http://www.huffpostarabi.com/majdi-moghera/-_1100_b_7997640.html

Maiese, M., \& Norlen, T. (2003). Polarization. Retrieved from http://www.beyondintractability.org/essay/polarization

Mansfield, P. (1973). Nasser and Nasserism. International Journal, 28(4), 670-688. doi:10.2307/40201172

Mansour, A. S. (2013). دستور مرسى: وسلب ثروات المصريين بالأوقاف: (9 / 7): الاوقاف و الأقباط [Endowments and Copts : Constitution of Morsi: and Robbing the Wealth of Egyptians with Endowments: (9/7): ]. Retrieved from http://www.ahlalquran.com/arabic/show_article.php?main_id=10602 
Masoud, T., \& Nawara, W. (2012, December 4). Will Egypt's liberals ever win? Slate. Retrieved from http://www.slate.com/articles/news_and_politics/foreigners/2012/12/egypt_s_libe rals_can_defeat_mohammad_morsi_if_they_ignore_the_muslim_brotherhood.ht $\mathrm{ml}$

Massacre in Cairo deepens Egypt crisis. (2013, July 7). Aljazeera. Retrieved from http://www.aljazeera.com/news/middleeast/2013/07/20137821320932698.html

McTighe, K. (2013, April 15). Egypt in dangerous state of limbo. $D W$. Retrieved from http://www.dw.com/en/egypt-in-dangerous-state-of-limbo/a-16744778

Mesalhy. (2013, July 3). General Al Sissi Strong speech [Video file]. Retrieved from https://www.youtube.com/watch? $\mathrm{v}=\mathrm{n}$ WKGeOuShQ

Midant-Reynes, B. (2000). The prehistory of Egypt: From the first Egyptians to the first pharaohs. Oxford, UK: Blackwell.

Mitchell, R. (1960). The Society of the Muslim Brothers (Doctoral dissertation). Available from ProQuest Dissertations and Theses database. (number)

Mitchell, R. (1993). The Society of the Muslim Brothers. New York, NY: Oxford University Press.

Mogahed, D. (2012, November 21). @saharazizlaw: Egypt's Constitutional Drafting Process Shows A Diverse Population Ready For Democracy $\mid$ http://shar.es/GSAAN. Retrieved from https://witter.com/dmogahed/status/271390755392745472

Mogahed, D. (2013). Winning Egypt's long war with extremism. Huffington Post. Retrieved from http://www.huffingtonpost.com/dalia-mogahed/winning-egyptslong-war-w_b_3655072.html

Mohsen, M. (2013, August 16). Health Ministry raises death toll of Wednesday's clashes to 638. Daily News Egypt. Retrieved from http://www.dailynewsegypt.com/2013/08/16/health-ministry-raises-death-toll-ofwednesdays-clashes-to-638/

Morgan, D. (1962). "An Interview with President Gamal Abdel Nasser.” The Sunday Times. Retrieved from http://nasser.bibalex.org/Common/pictures01$\% 20$ sira3_en.htm

Morgan, R. (2016). History of the Coptic Orthodox people and the Church of Egypt. Victoria, British Columbia: FriesenPress.

Mourad, M. R. (2011). محمود رضا مر اد [Mahmoud Reda Morad]. Retrieved from http://ara.reuters.com/article/topNews/idARACAE71O0GF20110225?pageNumb er $=1 \&$ virtualBrandChannel $=0 \& \mathrm{sp}=$ true

Nadler, A., Malloy, T. E, \& Fisher, J. D. (2008). The social psychology of intergroup reconciliation. New York, NY: Oxford University Press.

Nasserism. (n.d.). Retrieved from https://www.saylor.org/site/wpcontent/uploads/2011/06/Nasserism.pdf

Official vote result: $98.1 \%$ approves Egypt's post-June 30 constitution. (2014, January 18). Ahram Online. Retrieved from http://english.ahram.org.eg/News/91874.aspx

ORSAM Water Research Programme. (2013, September). Water wars: Egyptians condemn Ethiopia's Nile dam project. ORSAM Water Bulletin, 21-24. Retrieved from http://www.orsam.org.tr/files/Bultenler/SuBulteni/147.pdf 
Osman, T. (2011). Egypt on the brink from the rise of Nasser to the fall of Mubarak (Rev. ed.). New Haven: Yale University Press.

Ottaway, M. (2012). Who will write the Egyptian constitution? Retrieved from http://carnegieendowment.org/2012/03/13/who-will-write-egyptian-constitutionpub-47523

Patel, E. (2007). Acts of Faith: The Story of an American Muslim, the Struggle for the Soul of a Generation. Politics, Culture and Society Series. ISBN:0807077267, 9780807077269. Beacon Press, 2007

Podeh, E. (2011). The symbolism of the Arab flag in modern Arab states: Between commonality and uniqueness. Nations and Nationalism, 17(2), 419-442. doi:10.1111/j.1469-8129.2010.00475.x

Podeh, E., \& Winckler, O. (Eds.). (2004). Rethinking Nasserism: Revolution and historical memory in modern Egypt. Gainesville: University Press of Florida.

Post-Mubarak era public debates over Sharia in the constitution. (n.d.). Retrieved from http://www.islamopediaonline.org/country-profile/egypt/islam-andconstitution/post-mubarak-era-public-debates-over-sharia-constitution

Poundstone, W. (1992). Prisoner's dilemma (1st ed.). New York: Doubleday.

Profile: Egypt's Tamarod protest movement. (2013, July 1). BBC. Retrieved from http://www.bbc.com/news/world-middle-east-23131953

Rawlinson, G., \& Komroff, M. (1928). The history of Herodotus (The Library of Living Classics). New York, NY: Tudor.

Reid, D. (2015). Contesting antiquity in Egypt : Archaeologies, museums \& the struggle for identities from World War I to Nasser. Cairo ; New York: The American University in Cairo Press.

Roden, C. (2000). The new book of Middle Eastern food (Revised ed.). New York, NY: Alfred A. Knopf.

Rodney, W. (1972). How Europe underdeveloped Africa. London: Bogle-L'Ouverture.

Rothman, J. (1997). Resolving identity-based conflict in nations, organizations, and communities (1st ed., Jossey-Bass conflict resolution series). San Francisco, Calif.: Jossey-Bass.

Rousseau, D. M., Sitkin, S. B., Burt, R. S., \& Camerer, C. (1998). Not so different after all: A cross-discipline view of trust. Academy of Management Review, 23(3), 393-404. Retrieved from http://citeseerx.ist.psu.edu/viewdoc/download?doi=10.1.1.470.8322\&rep=rep1\&t ype $=$ pdf

Sabry, B. (2012, November 22). Absolute power: Morsi decree stuns Egyptians. AlMonitor. Retrieved from http://www.al-monitor.com/pulse/originals/2012/almonitor/morsi-decree-constitution-power.html

Sabry, B. (2013, May 19). Why only democracy can save Egypt. Al-Monitor. Retrieved from http://www.al-monitor.com/pulse/originals/2013/05/democracy-egyptfuture.html

Saleh, Y. (2013, September 8). Sinai Islamists claim responsibility for attack on Egypt minister. Reuters. Retrieved from http://www.reuters.com/article/us-egypt-attackinterior-idUSBRE9870BX20130908 
Salem, S., (2013, September 6). The Egyptian military and the 2011 revolution. jadaliyya.com. Jadaliyya. Retrieved from http://www.jadaliyya.com/pages/index/14023/the-egyptian-military-and-the2011-revolution

Sarhan, H. (2011). التعديلات الدستورية بمصر بين المؤيدين و الر افضين و المتحفظين [Constitutional Amendments in Egypt Between Supporters and Rejectors and Conservatives]. Retrieved from http://www.swissinfo.ch/ara/\%D8\%A7\%D9\%84\%D8\%AA\%D8\%B9\%D8\%AF\% D9\%8A\%D9\%84\%D8\%A7\%D8\%AA$\% \mathrm{D} 8 \% \mathrm{~A} 7 \% \mathrm{D} 9 \% 84 \% \mathrm{D} 8 \% \mathrm{AF} \% \mathrm{D} 8 \% \mathrm{~B} 3 \% \mathrm{D} 8 \% \mathrm{AA} \% \mathrm{D} 9 \% 88 \% \mathrm{D} 8 \% \mathrm{~B} 1 \% \mathrm{D} 9 \% 8 \mathrm{~A}$ $\% \mathrm{D} 8 \% \mathrm{~A} 9-\% \mathrm{D} 8 \% \mathrm{~A} 8 \% \mathrm{D} 9 \% 85 \% \mathrm{D} 8 \% \mathrm{~B} 5 \% \mathrm{D} 8 \% \mathrm{~B} 1-$ $\% \mathrm{D} 8 \% \mathrm{~A} 8 \% \mathrm{D} 9 \% 8 \mathrm{~A} \% \mathrm{D} 9 \% 86-$ \%D8\%A7\%D9\%84\%D9\%85\%D8\%A4\%D9\%8A\%D8\%AF\%D9\%8A\%D9\%86\%D9\%88\%D8\%A7\%D9\%84\%D8\%B1\%D8\%A7\%D9\%81\%D8\%B6\%D9\%8A\% D9\%86\%D9\%88\%D8\%A7\%D9\%84\%D9\%85\%D8\%AA\%D8\%AD\%D9\%81\%D8\%B8 $\% \mathrm{D} 9 \% 8 \mathrm{~A} \% \mathrm{D} 9 \% 86 / 29744746$

Sayyid-Marsot, A. (1977). Egypt's liberal experiment, 1922-1936. Berkeley: University of California Press.

Sayyid-Marsot, A. (1984). Egypt in the reign of Muhammad Ali. New York, NY: Cambridge University Press.

Shehadi, N., \& Mills, D. H. (Eds.). (1988). Lebanon: A history of conflict and consensus. London: Center for Lebanese Studies in association with I.B. Tauris.

Sheikh, N. S. (2003). The new politics of Islam: Pan-Islamic foreign policy in a world of states. London: RoutledgeCurzon.

Slackman, M. (2011. March 15). Islamist Group Is Rising Force in a New Egypt. Retrieved from: https://www.nytimes.com/2011/03/25/world/middleeast/25egypt.html

Slemon, S. (1996). Post-colonial critical theories. In B. King (Ed.), New national and post-colonial literatures: An introduction (pp. 178-97). Oxford, NY: Clarendon.

Slemon, S., \& Tiffin, H. (1989). Introduction. Kunapipi, 11(1). Retrieved from http://ro.uow.edu.au/kunapipi/vol11/iss 1/3

Slemon, S., \& Tiffin, H. (1989). Post-colonial criticism. Kunapipi, 11(1), Kunapipi, 1989, Vol.11(1).

Spencer, R. (2013, July 4). Egypt's army drives Mohammed Morsi from presidency and power in dramatic coup. The Telegraph. Retrieved from http://www.telegraph.co.uk/news/worldnews/africaandindianocean/egypt/101587 75/Egypts-army-drives-Mohammed-Morsi-from-presidency-and-power-indramatic-coup.html

Suleiman, Y. (1996). Language and identity in Egyptian nationalism. In Language and identity in the Middle East and North Africa (pp. 25-37). Richmond, London: Curzon.

Sultan, C. (Trans.). (2013, July 8). Interview with Egyptian politician ElBaradei: "This was not a coup." Retrieved from 
http://www.spiegel.de/international/world/interview-with-egyptian-politicianmohamed-elbaradei-a-909976.html

The 2014 Egyptian constitution: Without accountability, checks or balances. (2014, March 24). Daily News Egypt. Retrieved from

http://www.dailynewsegypt.com/2014/03/24/2014-egyptian-constitutionwithoutaccountability-checks-balances/

The Egyptian revolution: An interactive timeline. (n.d.). Retrieved from http://cdn.knightlab.com/libs/timeline/latest/embed/index.html? source=0AosmKb _cNQPdENSYTdUZUZfQ1ByWFlrR0pGUE90M3c\&font=PlayfairDisplayMuli\&maptype $=$ TERRAIN\&lang $=$ en $\&$ height $=800$

The Muslim Brotherhood "Project." (2016). Retrieved from https://www.investigativeproject.org/document/687-the-muslim-brotherhoodproject

The Napoleonic invasion of Egypt. (n.d.). Retrieved from http://napoleon.lindahall.org/learn.shtml

Tracy, J. L., \& Prehn, C. (2011). Arrogant or self-confident? The use of contextual knowledge to differentiate hubristic and authentic pride from a single nonverbal expression. Cognition and Emotion, 26(1). Retrieved from https://doi.org/10.1080/02699931.2011.561298

Turner, J. C., \& Tajfel, H. (1986). The social identity theory of intergroup behavior. Psychology of intergroup relations, 7-24.

Weaver, M., \& McCarthy, T. (2013). Muslim Brotherhood remains defiant. https://www.theguardian.com/world/middle-east-live/2013/jul/03/egyptcountdown-army-deadline-live

Wedeman, W., Sayah, R., \& Carter, C. J. (2013, July 6). 26 dead, more than 850 wounded as post-coup violence hits Egypt. CNN. Retrieved from http://edition.cnn.com/2013/07/05/world/meast/egypt-coup/index.html

Wodak, R., \& Boukala, S. (2015). European identities and the revival of nationalism in the European Union: A discourse historical approach. Journal of Language and Politics, 14(1), 87-109.

Wynn, L. L. (2007). Pyramids and nightclubs: A travel ethnography of Arab and Western imaginations of Egypt, from King Tut and a colony of Atlantis to rumors of sex orgies, urban legends about a marauding prince, and blonde belly dancers. Austin: University of Texas Press.

Yassin-Kassab, R. (2011, January 27). Scenes from the Egyptian intifada [Blog post]. Retrieved from https:/qunfuz.com/2011/01/27/scenes-from-the-egyptian-intifada/

Zeghal, M. (1999). Religion and politics in Egypt: The ulema of al-Azhar, radical Islam, and the state (1952-94). International Journal of Middle East Studies, 31(3), 371حملة سلفية "لاجهاض" مطالبات بألا يكون "الاسلام دين الدولة" في مصر . 
Choueiri, Y. M. (2000). Arab nationalism: A history: Nation and state in the Arab world. Oxford, UK: Blackwell.

MEMRI. (2014, December 31). Egyptian President al-Sisi at Al-Azhar: We must revolutionize our religion [Transcript]. Retrieved from https://www.memri.org/tv/egyptian-presidental-sisi-al-azhar-we-must-revolutionize-our-religion/transcript

Prakash, O. (n.d.). The transformation from a pre-colonial to a colonial order: The case of India. Retrieved from http://www.lse.ac.uk/EconomicHistory/Assets/Documents/Research/GEHN/GEHNConferences/conf2/Conf2OPrakash.pdf

Wodak, R. (2000, April). Does sociolinguistics need social theory? New perspectives in critical discourse analysis. Paper presented at SS2000, Bristol, England. Retrieved from https://www.univie.ac.at/linguistics/forschung/wittgenstein/unemploy/bristol5.htm

Wodak, R., \& Meyer, M. (2001). Methods of critical discourse analysis. London: SAGE. 